Article

\title{
Characterization and Parametric Study on Mechanical Properties Enhancement in Biodegradable Chitosan-Reinforced Starch-Based Bioplastic Film
}

\author{
Shiou Xuan Tan ${ }^{1} \mathbb{D}$, Hwai Chyuan Ong ${ }^{2, *(\mathbb{D}}$, Andri Andriyana ${ }^{1}$, Steven Lim ${ }^{3,4}, * \mathbb{D}$, Yean Ling Pang ${ }^{3,4} \mathbb{D}^{\mathbb{D}}$, \\ Fitranto Kusumo ${ }^{5}$ and Gek Cheng $\mathrm{Ngoh}^{6, *}$
}

check for updates

Citation: Tan, S.X.; Ong, H.C.; Andriyana, A.; Lim, S.; Pang, Y.L.; Kusumo, F.; Ngoh, G.C.

Characterization and Parametric Study on Mechanical Properties Enhancement in Biodegradable Chitosan-Reinforced Starch-Based Bioplastic Film. Polymers 2022, 14, 278. https://doi.org/10.3390/ polym14020278

Academic Editors: José Miguel Ferri, Vicent Fombuena Borràs and Miguel Fernando Aldás Carrasco

Received: 24 November 2021 Accepted: 24 December 2021 Published: 11 January 2022

Publisher's Note: MDPI stays neutral with regard to jurisdictional claims in published maps and institutional affiliations.

Copyright: (C) 2022 by the authors. Licensee MDPI, Basel, Switzerland. This article is an open access article distributed under the terms and conditions of the Creative Commons Attribution (CC BY) license (https:// creativecommons.org/licenses/by/ $4.0 /)$.
1 Department of Mechanical Engineering, Faculty of Engineering, Universiti Malaya, Kuala Lumpur 50603, Malaysia; kva190014@siswa.um.edu.my (S.X.T.); andri.andriyana@um.edu.my (A.A.)

2 Future Technology Research Center, National Yunlin University of Science and Technology, Douliou 64002, Taiwan

3 Department of Chemical Engineering, Lee Kong Chian Faculty of Engineering and Science, Universiti Tunku Abdul Rahman, Kajang 43000, Malaysia; pangyl@utar.edu.my

4 Centre of Photonics and Advanced Materials Research, Universiti Tunku Abdul Rahman, Kajang 43000, Malaysia

5 Centre for Green Technology, School of Civil and Environmental Engineering, University of Technology, Sydney, NSW 2007, Australia; Fitranto.Kusumo@student.uts.edu.au

6 Department of Chemical Engineering, Faculty of Engineering, Universiti Malaya, Kuala Lumpur 50603, Malaysia

* Correspondence: onghc@yuntech.edu.tw (H.C.O.); stevenlim@utar.edu.my (S.L.); ngoh@um.edu.my (G.C.N.)

\begin{abstract}
Bioplastic has been perceived as a promising candidate to replace petroleum-based plastics due to its environment-friendly and biodegradable characteristics. This study presents the chitosan reinforced starch-based bioplastic film prepared by the solution casting and evaporation method. The effects of processing parameters, i.e., starch concentration, glycerol loading, process temperature and chitosan loading on mechanical properties were examined. Optimum tensile strength of $5.19 \mathrm{MPa}$ and elongation at break of $44.6 \%$ were obtained under the combined reaction conditions of 5 wt. $\%$ starch concentration, $40 \mathrm{wt} . \%$ glycerol loading, $20 \mathrm{wt} . \%$ chitosan loading and at a process temperature of $70{ }^{\circ} \mathrm{C}$. From the artificial neural network (ANN) modeling, the coefficient of determination $\left(\mathrm{R}^{2}\right)$ for tensile strength and elongation at break were found to be 0.9955 and 0.9859 , respectively, which proved the model had good fit with the experimental data. Interaction and miscibility between starch and chitosan were proven through the peaks shifting to a lower wavenumber in FTIR and a reduction of crystallinity in XRD. TGA results suggested the chitosan-reinforced starch-based bioplastic possessed reasonable thermal stability under $290^{\circ} \mathrm{C}$. Enhancement in water resistance of chitosan-incorporated starch-based bioplastic film was evidenced with a water uptake of $251 \%$ as compared to a $302 \%$ registered by the pure starch-based bioplastic film. In addition, the fact that the chitosan-reinforced starch-based bioplastic film degraded to $52.1 \%$ of its initial weight after 28 days suggests it is a more sustainable alternative than the petroleum-based plastics.
\end{abstract}

Keywords: starch-based bioplastic; chitosan; co-polymer; reinforcement; biodegradation

\section{Introduction}

Petroleum-based plastics have constituted major parts of our daily life, ranging from bottled drinks, household appliances and toys to food packaging. The reasons for plastics having such popular usage are due to their high strength, low cost and light-weight as well as their thermal and chemical insulating properties [1,2]. However, petroleum-based plastics are resistant to chemical, solar and microbial degradation [1,3]. This leads to a build-up of plastic waste in the environment along with increasing utilization of plastic products $[4,5]$. The shortcomings can be addressed by the emergence of bioplastics. 
Bioplastics' renewable nature is associated with constituents that are derived from plants such as starch, cellulose and lignin or from animal-derived casein, protein and lipid [6]. Bioplastics have an edge over petroleum-based plastics due to their biodegradability, instead of the combustion of plastic wastes adopted by the latter [7,8]. Among the diverse feedstocks for synthesizing of bioplastic, starch is preferred, as it can be easily degraded into environment-friendly compounds [9]. In addition, its affordability, abundance and availability in various starch-producing plants such as sago, cassava, corn and potato have also added to its superior advantages. However, pure starch-based bioplastic film is hydrophilic and highly sensitive to water, which would negatively affect its mechanical and barrier properties, and thereby greatly limit its utilization [10-12].

In starch-based bioplastic film fabrication, plasticizer can be used to overcome film brittleness caused by the high intermolecular forces $[13,14]$. The commonly used plasticizers for starch-based bioplastic film are water, sorbitol and glycerol [15]. Nevertheless, it is not recommended for water to be used directly as plasticizer in view of the high volatility of its molecules, which would lead to brittleness in film [16,17]. Glycerol, conversely, possesses hydroxyl groups that are responsible for inter- and intra-molecular interactions (hydrogen bonds) in polymeric chains. Thus, it is regarded as the best plasticizer for water-soluble polymers in providing a more flexible structure for bioplastic films $[5,13,18]$.

The properties of pure starch-based bioplastic film could also be enhanced by blending it with other polymers such as chitosan with its hydrophobic nature $[19,20]$. Chitosan is obtained from the de-acetylation of chitin, which could be abundantly found in natural sources such as shells and heads of crabs, lobsters or shrimps [21,22]. The non-toxic and low-cost nature of chitosan has made it a suitable choice as a co-polymer in bioplastic film fabrication for improving mechanical properties, while reducing the hydrophilic characteristic of starch-based bioplastic film [19]. In addition, the bioplastic film produced from blending of starch with chitosan would be very attractive as a food-packaging application due to the intrinsic antimicrobial property of chitosan. Starch-based bioplastic films have been synthesized by many researchers from various sources, such as potato [23], corn [24,25], mango seed [26], jackfruit seed [27], sago [21], avocado seed [28] and cassava peel [29]. Despite bioplastic fabrication being conducted by many researchers, the parametric studies on plasticizer and filler/co-polymer loadings using solution and casting techniques are rarely being conducted. Possibly, this has been due to the restrictions of smaller scale (laboratory scale), which was less developed in its present status. Moreover, the results obtained had not been proven for industrial scale compared to other matured techniques such as extrusion, blow molding and compression molding. The effects of starch concentration and process temperature on the mechanical properties of bioplastic film are also seldom being investigated and their relationships are still unclear. Hence, this paper aims to provide more insights into the effects of operating parameters, including starch concentration, glycerol loading, process temperature and chitosan loading on the mechanical properties of the synthesized bioplastic film, based on the solution casting and evaporation technique. The present work employs corn starch as matrix, chitosan as co-polymer and glycerol as plasticizer in the fabrication of a sustainable bioplastic film. The results of this parametric study on the mechanical properties of the starch-based bioplastic film will develop a fundamental framework for more in-depth studies in the future. Artificial neural network (ANN) was adopted in this study in order to compare the experimental and predicted tensile strength and elongation at break. In addition, pure starch-based and chitosan-reinforced starch-based bioplastic films were compared in terms of their water uptake capability and actual biodegradability in soil to address the future of applicability of bioplastics.

\section{Materials and Methods}

\subsection{Materials}

Corn starch powder was procured from Thye Huat Chan Sdn. Bhd., Malaysia. Glycerol (99.5\% purity) was procured from Friendemann Schmidt. Acetic acid (glacial, 100\% purity) 
and chitosan (from shrimp shells, medium molecular weight) were purchased from Merck and Sigma-Aldrich, respectively. Laboratory-formulated distilled water was used throughout the experiments. All the chemicals were used as received, without further purification.

\subsection{Preparation of Corn Starch Bioplastic Film}

The solution casting and evaporation method was adopted for bioplastic film preparation in this study. The formulation was modified from the work of Salehudin et al. [30]. A schematic diagram of the experimental setup is shown in Figure 1. First, a varying amount of corn starch (2.5 wt.\%-10 wt.\% of distilled water), which corresponded to starch: glycerol ratio $(w / w)$ of 10:8-40:8 was added into a $250 \mathrm{~mL}$ beaker containing $100 \mathrm{~mL}$ distilled water in a form of suspension to avoid agglomeration. The starch solution was homogenized at $250 \mathrm{rpm}$ and heated at $60^{\circ} \mathrm{C}$ for $15 \mathrm{~min}$. Glycerol of varying weight percentages (40 wt.\%-80 wt.\% based on weight of starch only) was added into the starch solution and subjected to different process temperatures $\left(65^{\circ} \mathrm{C}-90^{\circ} \mathrm{C}\right)$ until it was gelatinized. For the addition of varying chitosan loading $(0 \mathrm{wt} . \%-20 \mathrm{wt} . \%$ of starch), chitosan was dispersed in aqueous solution of $1 \mathrm{v} / \mathrm{v} \%$ acetic acid. Upon completion of the reaction, $15 \mathrm{~g}$ of starch mixture or starch-chitosan mixture was poured into a square container with dimension of $10 \mathrm{~cm} \times 10 \mathrm{~cm}$. The mixture was then dried in a heating oven at $60^{\circ} \mathrm{C}$ for $24 \mathrm{~h}$. The film was peeled off and stored in a desiccator with a sealed plastic bag prior to thickness measurement and further testing. The final thickness of each film was measured and was in the range of $0.11 \pm 0.02 \mathrm{~mm}$. The effects of fabrication parameters, including starch concentration, glycerol loading, process temperature and chitosan loading towards the mechanical properties of corn starch bioplastic film were investigated using the one factor at a time method. Each experiment was conducted in triplicates to ensure the data reproducibility. The reported values were the average of the individual runs, with errors within an acceptable range of 5\%. The pure starch-based and chitosan-reinforced starch-based bioplastic films with the optimum tensile strength were then subjected to water uptake and biodegradation tests to further characterize the bioplastic properties.

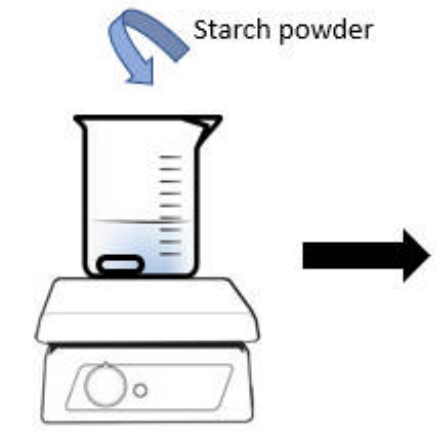

Add starch powder into distilled water. Stir and heat for $15 \mathrm{~min}$ for homogenization.
Glycerol
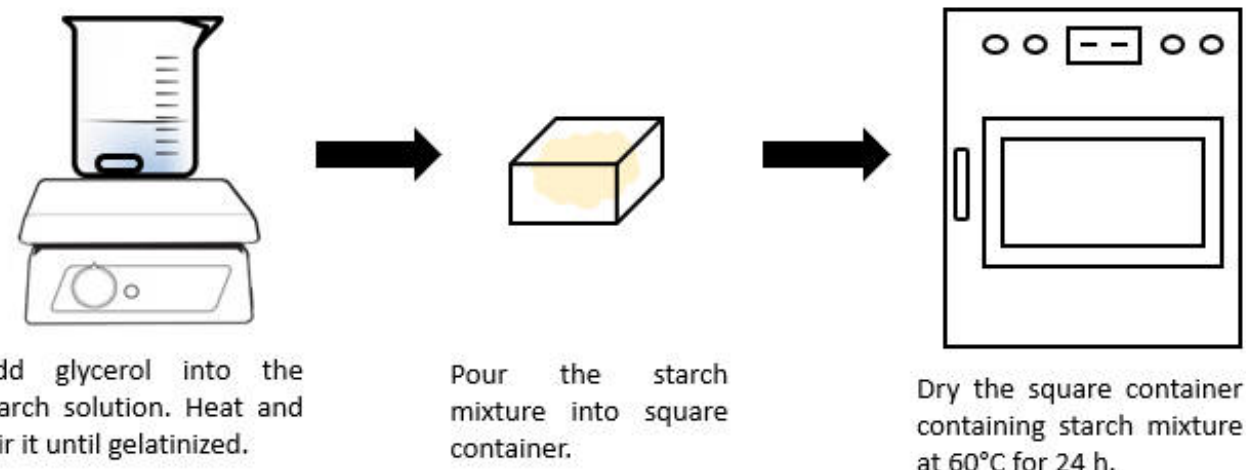

Dry the square container containing starch mixture at $60^{\circ} \mathrm{C}$ for $24 \mathrm{~h}$.

Figure 1. Experimental setup for bioplastic film fabrication.

\subsection{ANN Modeling}

The ANN model was developed using MATLAB Version 7.10 R2010a software (The MathWorks Inc., Natick, MA, USA). In this study, the hyperbolic tangent sigmoid transfer function (tansig) was used for the input layer to the hidden layer and the linear transfer function (purelin) was used from the hidden layer to the output layer. Once the mean squared error (MSE) reached the minimum value and the average correlation coefficient (R) was close or equal to 1 , the training of ANN model was terminated. 


\subsection{Data Verification}

The performance of the ANN model was measured statistically based on the coefficient of determination $\left(\mathrm{R}^{2}\right)$ according to Equation (1) [31]. Generally, a higher $\mathrm{R}^{2}$ value indicated higher accuracy for the developed model.

$$
R^{2}=1-\sum_{i=1}^{n}\left(\frac{\left(y_{b i}-y_{p i}\right)^{2}}{\left(y_{m}-y_{p i}\right)^{2}}\right)
$$

where $n$ is the number of experimental data, while $y_{b i}$ is the experimental tensile strength/elongation at break, $y_{p i}$ is the predicted tensile strength/elongation at break and $y_{m}$ is the average value of the tensile strength/elongation at break obtained from the experiments.

\subsection{Characterization of Bioplastic Film}

\subsubsection{Mechanical Properties}

The mechanical properties of bioplastic film such as tensile strength and elongation at break were determined using Universal Testing Machine (Autograph AG-X, Shimadzu, Japan) interfaced with computer operating Trapezium software. Measurements were performed with load cell of $500 \mathrm{~N}$, crosshead speed of $5 \mathrm{~mm} / \mathrm{min}$ and grip separation of $30 \mathrm{~mm}$. Three readings were taken from three random places of each film, measuring $7 \mathrm{~cm} \times 1 \mathrm{~cm}$. The average values from three measurements were reported.

\subsubsection{Fourier-Transform Infrared (FTIR) Analysis}

FTIR spectra of pure starch-based and chitosan-reinforced starch-based bioplastic films were recorded using FTIR spectrometer operating in attenuated total reflectance (ATR) mode by positioning the measuring probe directly on the film surface (Perkin Elmer, model Spectrum 400) to compare the functional groups and chemical bonds between the films. FTIR spectra of corn starch and chitosan powders were also acquired by placing the samples on the test area. All the samples were scanned at a frequency range of $4000-450 \mathrm{~cm}^{-1}$ with 32 scans at a resolution of $4 \mathrm{~cm}^{-1}$.

\subsubsection{X-ray Diffraction (XRD)}

XRD patterns were recorded using an X-ray diffractometer (Rigaku, model MiniFlex $300 / 600$ ) equipped with $\mathrm{CuK} \alpha$ radiation, operating at $40 \mathrm{kV}$ and $14 \mathrm{~mA}$. All the samples were measured at room temperature over the angular range $3-90^{\circ}(2 \theta)$ at a step size of $0.02^{\circ}$ in continuous mode.

\subsubsection{Thermal Analysis}

Thermal behaviors of pure starch-based and chitosan-reinforced starch-based bioplastic films were characterized by thermal gravimetric analysis (TGA). This thermal decomposition analysis was performed by using a thermogravimetric analyzer (Perkin Elmer, model TGA Pyris 1). A bioplastic film of around $5 \mathrm{mg}$ was placed in a platinum pan and heated from ambient temperature to a final temperature of $900{ }^{\circ} \mathrm{C}$ at a heating rate of $20^{\circ} \mathrm{C} / \mathrm{min}$ with nitrogen flow rate of $50 \mathrm{~mL} / \mathrm{min}[19,32]$.

\subsubsection{Water Uptake Test}

The water uptake test was modified from the study of Maulida and Tarigan [29] and $\mathrm{Wu}$ [33]. Bioplastic film was cut into a uniform size of $2 \mathrm{~cm} \times 2 \mathrm{~cm}$ with its mass being weighed. The film was then immersed in a container filled with distilled water for $90 \mathrm{~min}$. During the period, the film was removed from the water at 10-min intervals. Immediately after it was blotted dried with tissue paper, the film was weighed before returning to the 
water. The water uptake by the film was calculated according to Equation (2) [4]. The average values from three measurements were reported.

$$
\text { Water uptake }=\frac{W-W_{o}}{W_{o}} \times 100 \%
$$

where $W_{o}$ is the weight of dry sample (g), $W$ is the weight of sample after immersion in distilled water $(\mathrm{g})$

\subsubsection{Biodegradation Test}

Bioplastic samples with the dimension $2 \mathrm{~cm} \times 2 \mathrm{~cm}$ were buried in compost soil purchased from a local plant nursery at $\pm 3 \mathrm{~cm}$ depth and left for 28 days with weekly sampling being performed. The buried samples were cleaned of soil and weighed. The biodegradation test was conducted at room temperature with relative humidity of $40-50 \%$. The weight loss of the bioplastics was calculated using Equation (3) [9]. Three replicates of each sample were subjected to the biodegradation test and the average values were reported.

$$
\text { Weight loss }=\frac{W_{o}-W_{f}}{W_{o}} \times 100 \%
$$

where $W_{o}$ is the initial bioplastic weight $(\mathrm{g}), W_{f}$ is the final bioplastic weight $(\mathrm{g})$.

\subsection{Statistical Analysis}

Statistical analysis was performed on OriginPro 2018 software (OriginLab, USA). Oneway analysis of variance (ANOVA) with Tukey test was performed to compare the mean values at the significance level of $5 \%(p<0.05)$.

\section{Results and Discussion}

\subsection{Mechanical Properties}

\subsubsection{Effect of Starch Concentration}

The effects of starch concentration on the mechanical properties that were evaluated by fixing a glycerol amount of $2 \mathrm{~g}$ and a process temperature of $70^{\circ} \mathrm{C}$ without incorporation of chitosan are presented in Figure 2. The tensile strength of bioplastic film decreased significantly from $3.22 \mathrm{MPa}$ to $0.78 \mathrm{MPa}(p<0.05)$ and so did the elongation at break, indicating a substantial drop from $53.6 \%$ to $41.6 \%(p<0.05)$ with the addition of starch concentration from $2.5 \mathrm{wt} . \%$ to $7.5 \mathrm{wt} . \%$. The significant decrement of $75.8 \%$ in tensile strength could be explained by the increase in amylopectin content as the starch concentration increased. The branched structure of amylopectin created a distance between the polymer chains resulting in weaker hydrogen bonds between them [21,34]. These research findings were in accord with the work of Sapei et al. [34] on the effects of different banana starch concentrations (10 to $30 \mathrm{vol} . \%$ ) on the mechanical properties of chitosan-starch bioplastic film. It was worth noting that a very brittle bioplastic film was formed at $10 \mathrm{wt} . \%$ starch concentration. The brittleness incapacitated the tensile test, which can be evidenced from Table 1 exhibiting the cracked film with small broken pieces. This finding revealed that a $10 \mathrm{wt} . \%$ starch solution was too saturated to produce a smooth and uniform film whereas glycerol at $40 \mathrm{wt} . \%$ was insufficient to facilitate the formation of a film. The decrease in the elongation at break could be explained through the saturation phenomenon, whereby the bondings between the starch molecules increased as the starch concentration was increased to a saturation amount that would prevent glycerol molecules to fit into the molecular chains [35]. 


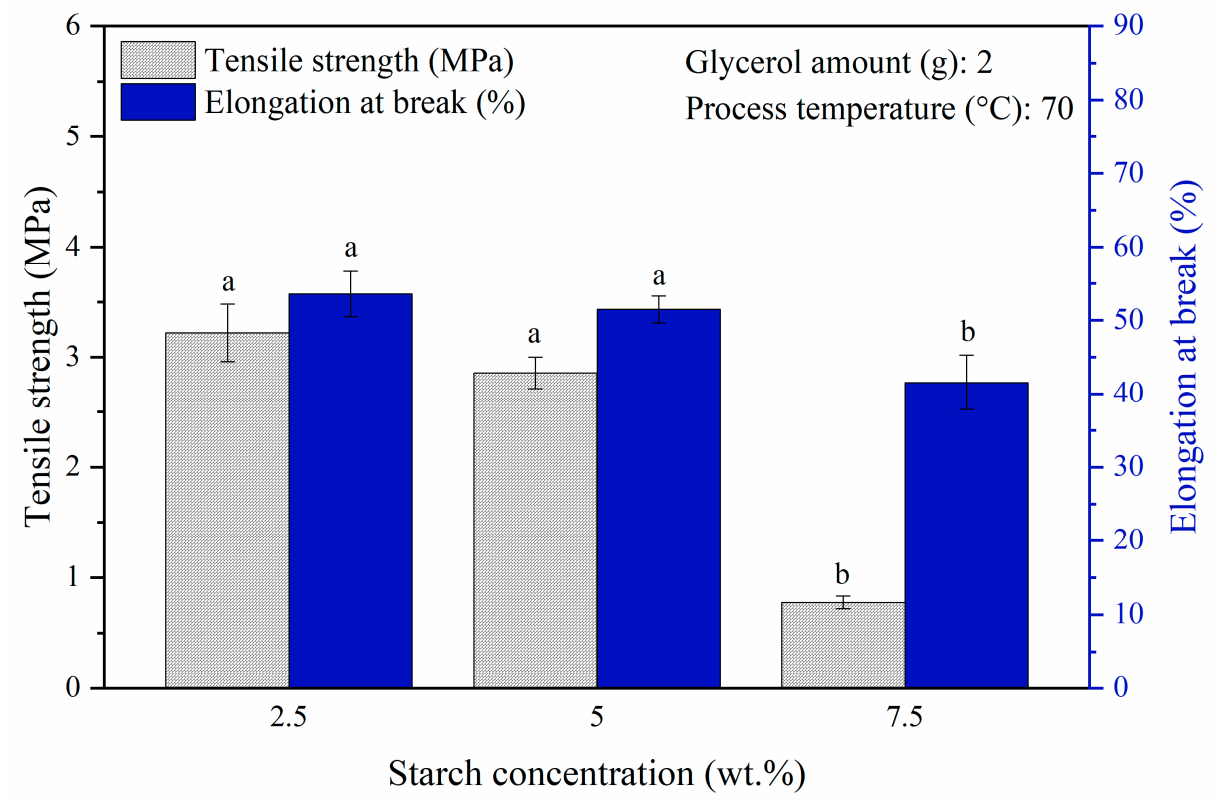

Figure 2. Tensile strength and elongation at break of pure starch-based bioplastic films at different starch concentrations. Different letters indicate the values are significantly different $(p<0.05)$.

Table 1. Gelatinized duration required and film appearance at different starch concentrations. 
Table 1. Cont.

\begin{tabular}{ccc}
\hline Starch Concentration (wt.\%) & Gelatinized Duration (h) & Film Appearance \\
\hline & & Brittle film. \\
\hline
\end{tabular}

To gain an insightful overview of the starch synthesized bioplastic film and the effects on its mechanical properties, gelatinized duration required and appearance of film at diverse starch concentrations are presented in Table 1. In general, the surface of bioplastic film in contact with the container was shinny and glossy; meanwhile, the surface exposed to air during drying was dull looking. Starch is responsible for the cohesion of bioplastic during heating; a lower starch concentration required a longer heating process and would consume a greater energy consumption to evaporate the water content in achieving cohesion of bioplastic [36]. Despite that at $2.5 \mathrm{wt} . \%$ starch concentration, the bioplastic film possessed tensile strength that was $11.2 \%$ higher than that of $5 \mathrm{wt} . \%$ starch concentration, the gelatinization duration was $3.5 \mathrm{~h}$ longer. This implied $2.5 \mathrm{wt} . \%$ was not feasible to be considered as the optimum starch concentration from an economic perspective. Therefore, a $5 \mathrm{wt} . \%$ starch concentration was used to optimize the subsequent parameter investigated.

\subsubsection{Effect of Glycerol Loading}

Glycerol was used as a plasticizer to synthesize bioplastic in the present study to reduce the film brittleness by reducing the intermolecular forces between polymer chains, while increasing their mobility to produce a more elastic and flexible film [37]. From the findings of varying glycerol loadings ( $40 \mathrm{wt} . \%$ to $80 \mathrm{wt} . \%$ at $10 \mathrm{wt} . \%$ increments, which corresponded to starch: glycerol ratio $(w / w)$ of 20:8 to 20:16) on the mechanical properties of the synthesized bioplastic film, the results in Figure 3 show that tensile strength exhibited a decreasing trend, in which it dropped from $2.86 \mathrm{MPa}$ to $0.24 \mathrm{MPa}$ when the glycerol loading was increased from $40 \mathrm{wt} . \%$ to $80 \mathrm{wt} . \%$, and in contrast the elasticity of the film showed an opposite trend $(p<0.05)$. This could be reflected from the significant increase of $24.6 \%$ (from $51.5 \%$ to $76.1 \%$ ) in the elongation at break value within the investigated range of glycerol loading. Higher glycerol loading provides greater free-movement space for the glycerol molecules to slip between the amylose-amylopectin chains. This weakens the interaction between the polymer in preventing the formation of rigid structures, while softening the polymer matrix, simultaneously [38]. The same behavioral plasticizing effect of glycerol on starch-based bioplastic film was observed by Ginting et al. [38] and Santana et al. [39] in the fabrication of durian seed starch-chitosan-sorbitol and cassava starchglycerol films, respectively. Glycerol of $40 \mathrm{wt} . \%$ was used to optimize the subsequent parameters investigated, as the film obtained at lower amount of $30 \mathrm{wt} . \%$ glycerol was too brittle to be subjected for tensile test. 


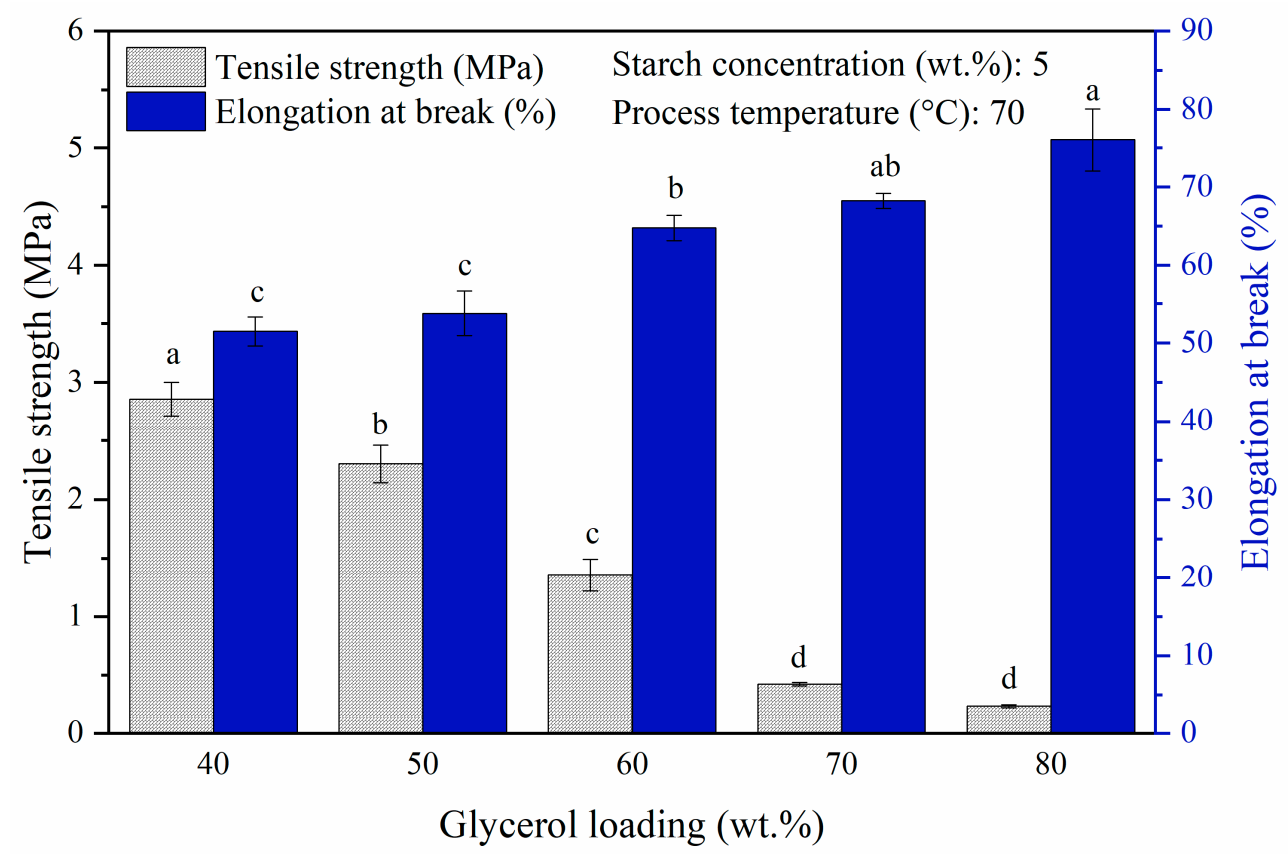

Figure 3. Tensile strength and elongation at break of pure starch-based bioplastic films with varying glycerol loadings. Different letters indicate the values are significantly different $(p<0.05)$.

\subsubsection{Effect of Process Temperature}

Temperature always exerts an effect on reaction. Preliminary study indicated that process temperature below $65{ }^{\circ} \mathrm{C}$ did not successfully produce a film. To elucidate the temperature effect on the fabrication of bioplastic, temperatures ranging from $65{ }^{\circ} \mathrm{C}$ to $90^{\circ} \mathrm{C}$ were applied to the bioplastic solution and their effects on the mechanical properties of the bioplastic film are shown in Figure 4. When the process temperature increased from $65{ }^{\circ} \mathrm{C}$ to $70{ }^{\circ} \mathrm{C}$, the tensile strength of the bioplastic film increased from $1.52 \mathrm{MPa}$ to an optimum value of $2.86 \mathrm{MPa}$ within the range of the investigated temperature $(p<0.05)$. The temperature increased from $65^{\circ} \mathrm{C}$ to $70{ }^{\circ} \mathrm{C}$ had induced gelatinization by producing a film that is free of air bubbles, which can be observed from Table 1 . However, tensile strength had then dropped to $1.96 \mathrm{MPa}$ as the process temperature further increased to $90{ }^{\circ} \mathrm{C}(p<0.05)$. The declining of tensile strength at higher process temperature might be caused by the weakening of intermolecular bonds in starch as excessive heating breaks the glycosidic bonds (bonds between monomers) in amylose [38]. Amylose plays an important role in the gel formation and the production of compact thin film. The excessive heat provided at $90{ }^{\circ} \mathrm{C}$ resulted in the depolymerization of long chain amylose into short chain amylose. This has subsequently decreased the amylose content [40,41]. A reduction in amylose content lowers the cohesiveness of bioplastics formation and, thus, its tensile strength is decreased [38].

Moreover, elongation at break increased with increasing process temperature. The highest investigation temperature of $90{ }^{\circ} \mathrm{C}$ gave rise to the longest elongation at break of $71.0 \%$. At lower process temperature, the molecules in the polymer matrix are closely packed with lower kinetic energy. Thus, small free volume is present within the polymer matrix and the movement of the molecules are somewhat restricted. As the process temperature increases, the higher kinetic and thermal energies imparted to the polymer molecules could trigger more intense vibrations and generate more free volumes available for larger molecular chain rotation in the solution [42]. This suggests that besides the addition of glycerol, increase in the free volume between the polymer chains can also be achieved with increase in temperature. Eventually, the increasing mobility of starch molecules and the softening of film matrix would synergistically increase the flexibility of the synthesized film. This could be observed from the increase of $31.2 \%(39.8 \%$ to $71.0 \%)$ in the elongation at break percentage of bioplastic film as the process temperature was elevated 
from $65^{\circ} \mathrm{C}$ to $90{ }^{\circ} \mathrm{C}(p<0.05)$ [42,43]. Furthermore, Ginting et al. [38] also reported similar trends of tensile strength and elongation at break with respect to the process temperature. Both the optimum tensile strength and elongation at break, respectively, of $19 \mathrm{MPa}$ and $2.6 \%$ were obtained at $70{ }^{\circ} \mathrm{C}$ when durian seed starch was used as matrix, sorbitol as plasticizer and chitosan as co-polymer.

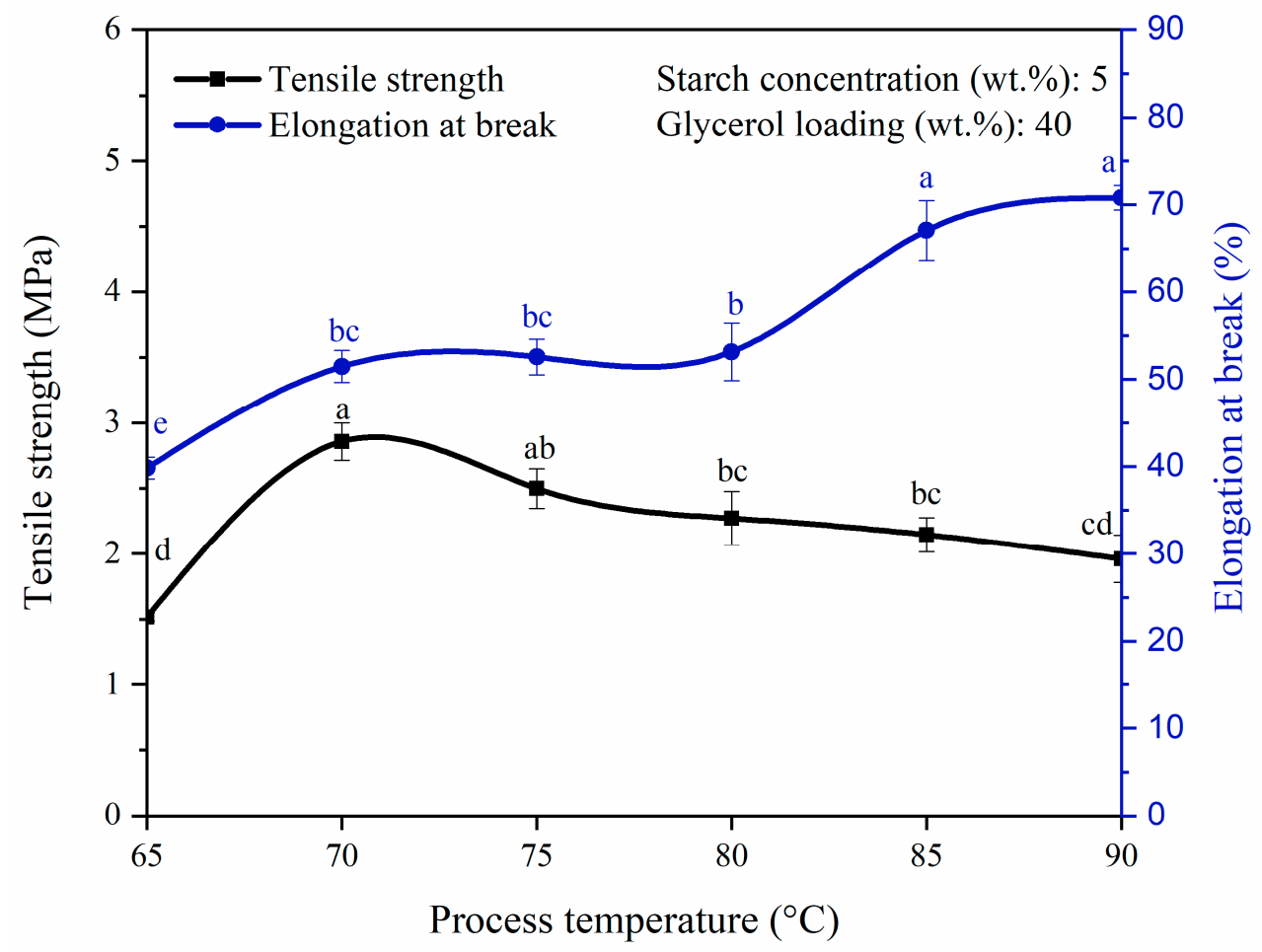

Figure 4. Tensile strength and elongation at break of pure starch-based bioplastic films at different process temperatures. Different letters indicate the values are significantly different $(p<0.05)$.

\subsubsection{Effect of Chitosan Loading}

The effects of chitosan loading $(0 \mathrm{wt} . \%$ to $20 \mathrm{wt} . \%$, which corresponded to starch: glycerol: chitosan ratio $(w / w)$ of 20:8:0 to 20:8:1) on the mechanical properties of bioplastic film are shown in Figure 5. With the addition of $5 \mathrm{wt} . \%$ chitosan loading, the tensile strength was improved to $3.86 \mathrm{MPa}$, which was 1.35 times greater than that of the pure starch-based bioplastic film at $2.86 \mathrm{MPa}(p<0.05)$. Further increase in the chitosan loading to $20 \mathrm{wt} . \%$ resulted in the tensile strength increasing to $5.19 \mathrm{MPa}(p<0.05)$. The reinforcement in the tensile strength could be attributed to the presence of more hydrogen bonds between $\mathrm{NH}_{3}{ }^{+}$of the chitosan and $\mathrm{OH}^{-}$of the corn starch. The amino groups $\left(\mathrm{NH}_{2}\right)$ from chitosan were protonated to $\mathrm{NH}_{3}{ }^{+}$in the acetic acid solution, while the orderly arranged crystalline structure of starch molecules was disrupted during the gelatinization process, resulting in the $\mathrm{OH}^{-}$groups being exposed to form hydrogen bonds with $\mathrm{NH}_{3}{ }^{+}$of the chitosan. Hence, chemical bonds of the bioplastic film were stronger and harder to be broken $[27,38,44]$. In contrast to the trend in tensile strength, elongation at break showed a decreasing trend with higher chitosan loading, although the perceived difference was not very significant $(p>0.05)$. Pure starch-based bioplastic film had elongation at break of $51.5 \%$, whereas the chitosan-incorporated starch-based bioplastic film had elongation at break of $47.9 \%$ with $5 \mathrm{wt} . \%$ chitosan loading. When the chitosan loading was increased to $20 \mathrm{wt} . \%$, the lowest elongation at break of $44.6 \%$ was obtained and similar results were reported by Hasan and Rahmayani [4] on the negative effect exerted by the increase in chitosan loading on the film flexibility. Another study published in the literature also demonstrated the improvement of tensile strength but lower elongation of break by $25 \mathrm{wt} . \%$ of chitosan loading in starch-based bioplastic film [27]. The tensile strength demonstrated in the 
published study [27] was higher than that of the present study (13.52 MPa vs. 5.19 MPa). In addition to the higher chitosan loading demonstrated in the published study ( $25 \mathrm{wt} . \% \mathrm{vs}$. 20 wt.\%), this observation could be due to different plasticizers employed in both studies, in which sorbitol was employed. Sorbitol has six hydroxyl groups, which is double the number of hydroxyl groups compared to the glycerol. Sorbitol could bind more hydroxyl groups to the starch via hydrogen bonding, thereby achieving higher tensile strength than the present study [45].

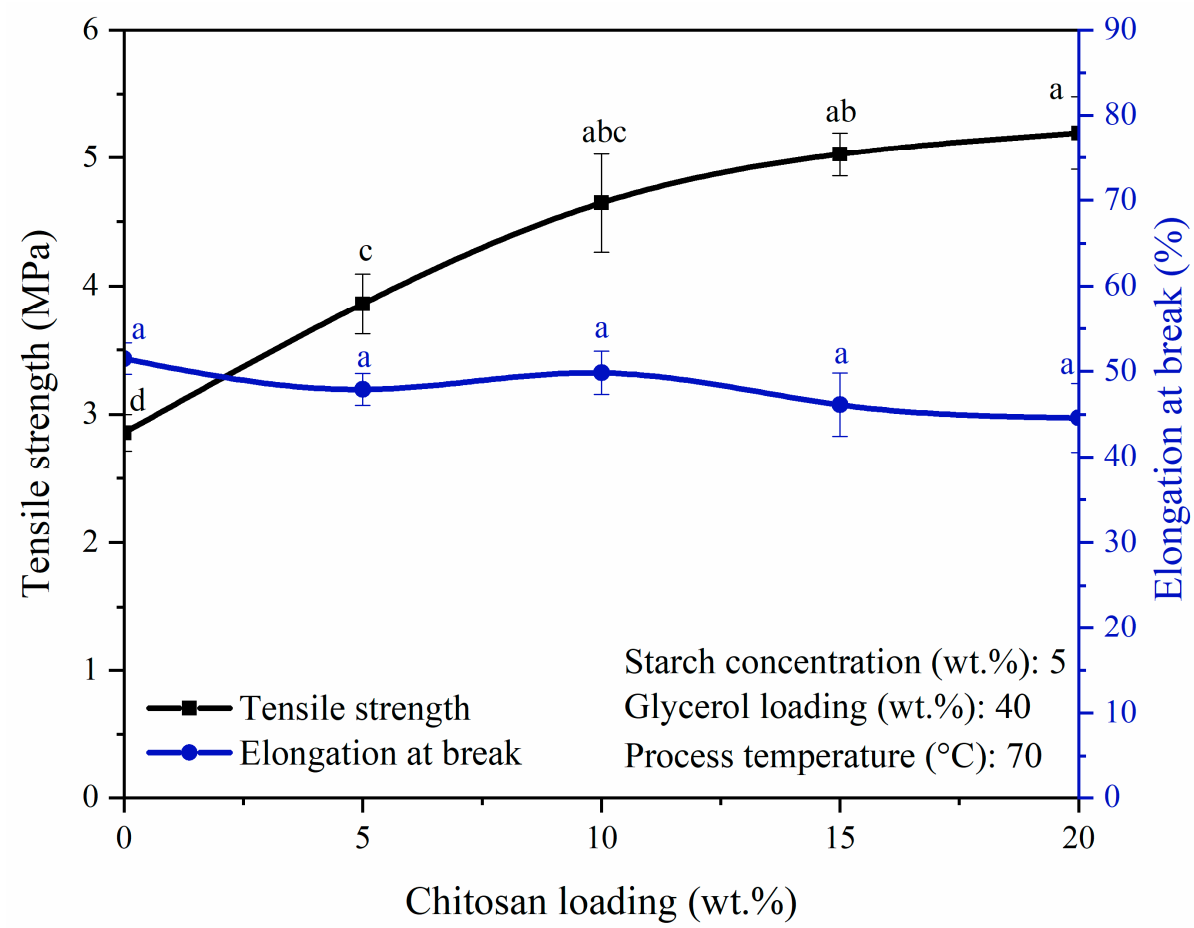

Figure 5. Tensile strength and elongation at break of bioplastic films at various chitosan loadings. Different letters indicate the values are significantly different $(p<0.05)$.

In the present study, optimum tensile strength was determined at $20 \mathrm{wt} \%$ chitosan loading. It is apparent that when the additional $5 \mathrm{wt}$ \% chitosan loading was added, chitosan could not be dissolved completely in the starch solution leading to chitosan aggregation and the formation of numerous big lumps.

\subsection{ANN Modeling Results}

A total of 16 experimental runs were conducted using four input variables, i.e., starch concentration, glycerol loading, process temperature and chitosan loading and two output variables, i.e., average tensile strength and average elongation at break. The experimental data were randomly divided into $60 \%$ for the training, $20 \%$ for testing and $20 \%$ for validation. Based on the heuristic procedure, the optimum numbers of hidden neurons that fulfilled the requirements of minimum MSE and maximum $\mathrm{R}$ were 4 for tensile strength and 3 for elongation at break. Thus, the best topology was found to be 4-4-1 for tensile strength (Figure 6) and 4-3-1 for elongation at break (Figure 7) prediction. The values of $\mathrm{R}$ for training, validation, test and all, for tensile strength were 1, 0.97975, 0.99123 and 0.99552 , respectively, (Figure 8). For elongation at break, the values of $\mathrm{R}$ for training, validation, test and all, were 0.99149, 0.99897, 0.99781 and 0.98593, respectively, (Figure 9). It could be observed from Tables 2 and 3 that the values of $\mathrm{R}^{2}$ for tensile strength and elongation at break were 0.9955 and 0.9859 , respectively, which were very close to unity. Therefore, it could be concluded that the model had good fit with the experimental data [46]. 


$\begin{array}{lcc}\text { Input } & \text { Hidden } & \text { Output } \\ \text { Layer } & \text { Layer } & \text { Layer }\end{array}$

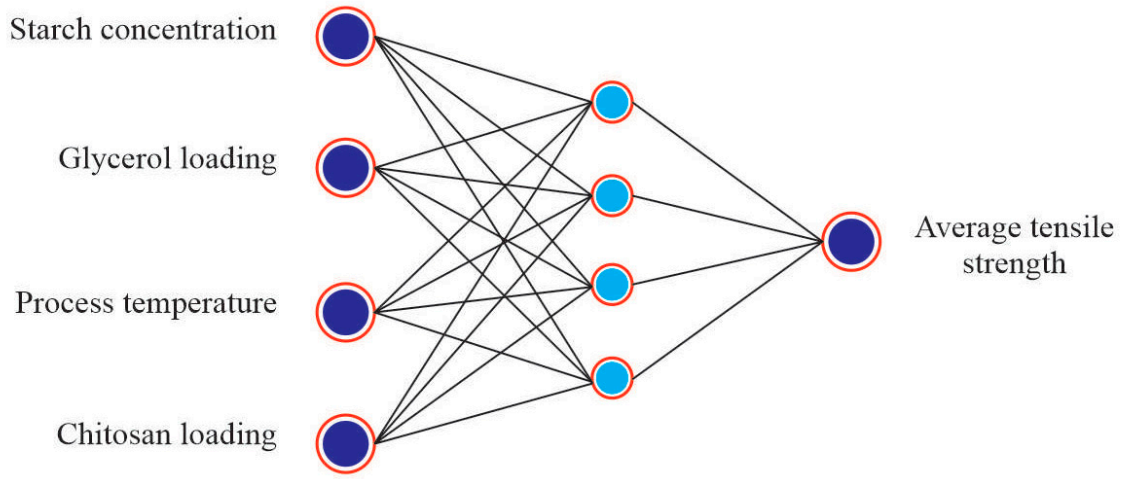

Figure 6. Architecture of ANN model for tensile strength.

$\begin{array}{ccc}\text { Input } & \text { Hidden } & \text { Output } \\ \text { Layer } & \text { Layer } & \text { Layer }\end{array}$

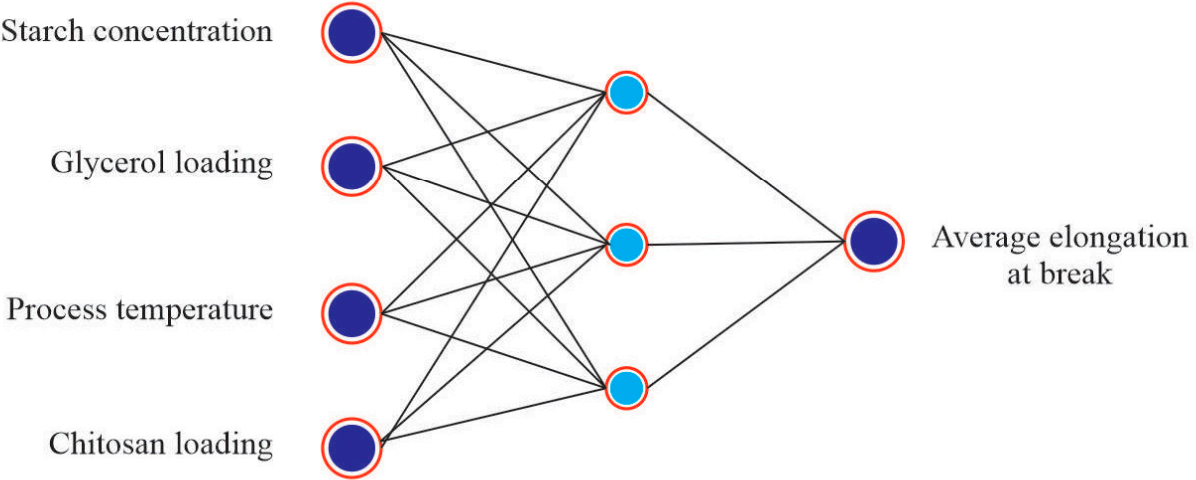

Figure 7. Architecture of ANN model for elongation at break.

Table 2. Comparison of the experimental tensile strength and predicted tensile strength by ANN model.

\begin{tabular}{|c|c|c|c|c|c|c|}
\hline $\begin{array}{l}\text { Experimental } \\
\text { Run }\end{array}$ & $\begin{array}{c}\text { Starch } \\
\text { Concentration } \\
(w t . \%)\end{array}$ & $\begin{array}{c}\text { Glycerol } \\
\text { Loading (wt.\%) }\end{array}$ & $\begin{array}{c}\text { Process } \\
\text { Temperature } \\
\left({ }^{\circ} \mathrm{C}\right)\end{array}$ & $\begin{array}{c}\text { Chitosan } \\
\text { Loading (wt.\%) }\end{array}$ & $\begin{array}{c}\text { Experimental } \\
\text { Tensile } \\
\text { Strength (MPa) }\end{array}$ & $\begin{array}{c}\text { Predicted } \\
\text { Tensile } \\
\text { Strength (MPa) }\end{array}$ \\
\hline 1 & 2.5 & 40 & 70 & 0 & 3.22 & 3.22 \\
\hline 2 & 5 & 40 & 70 & 0 & 2.86 & 2.85 \\
\hline 3 & 7.5 & 40 & 70 & 0 & 0.78 & 0.78 \\
\hline 4 & 5 & 50 & 70 & 0 & 2.30 & 2.29 \\
\hline 5 & 5 & 60 & 70 & 0 & 1.36 & 1.30 \\
\hline 6 & 5 & 70 & 70 & 0 & 0.42 & 0.51 \\
\hline 7 & 5 & 80 & 70 & 0 & 0.24 & 0.23 \\
\hline 8 & 5 & 40 & 65 & 0 & 1.52 & 1.52 \\
\hline 9 & 5 & 40 & 75 & 0 & 2.50 & 2.94 \\
\hline 10 & 5 & 40 & 80 & 0 & 2.27 & 2.20 \\
\hline 11 & 5 & 40 & 85 & 0 & 2.15 & 2.14 \\
\hline 12 & 5 & 40 & 90 & 0 & 1.96 & 2.34 \\
\hline 13 & 5 & 40 & 70 & 5 & 3.86 & 3.86 \\
\hline 14 & 5 & 40 & 70 & 10 & 4.65 & 4.68 \\
\hline 15 & 5 & 40 & 70 & 15 & 5.03 & 5.02 \\
\hline 16 & 5 & 40 & 70 & 20 & 5.19 & 5.18 \\
\hline$R^{2}$ & 0.9955 & & & & & \\
\hline
\end{tabular}



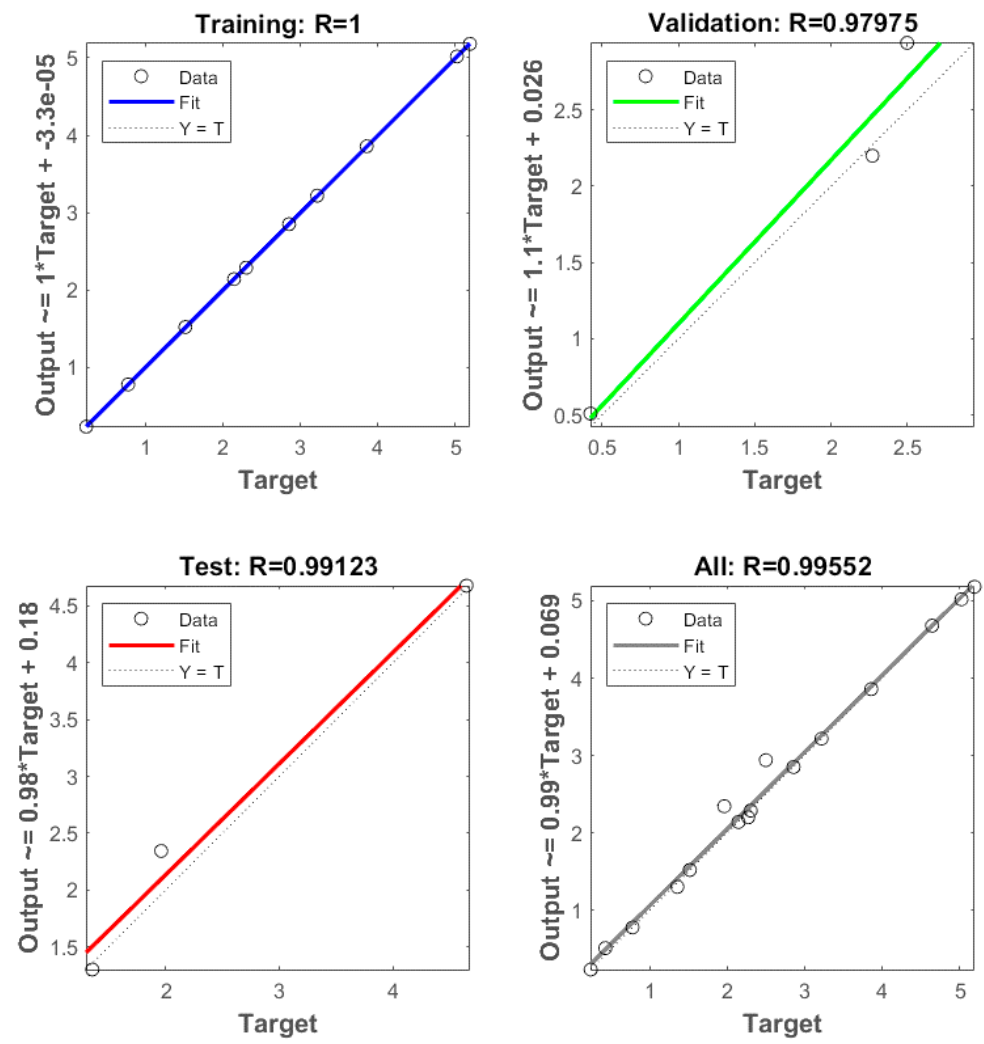

Figure 8. Coefficient of correlation (R) values of training, validation testing and overall datasets, for tensile strength.
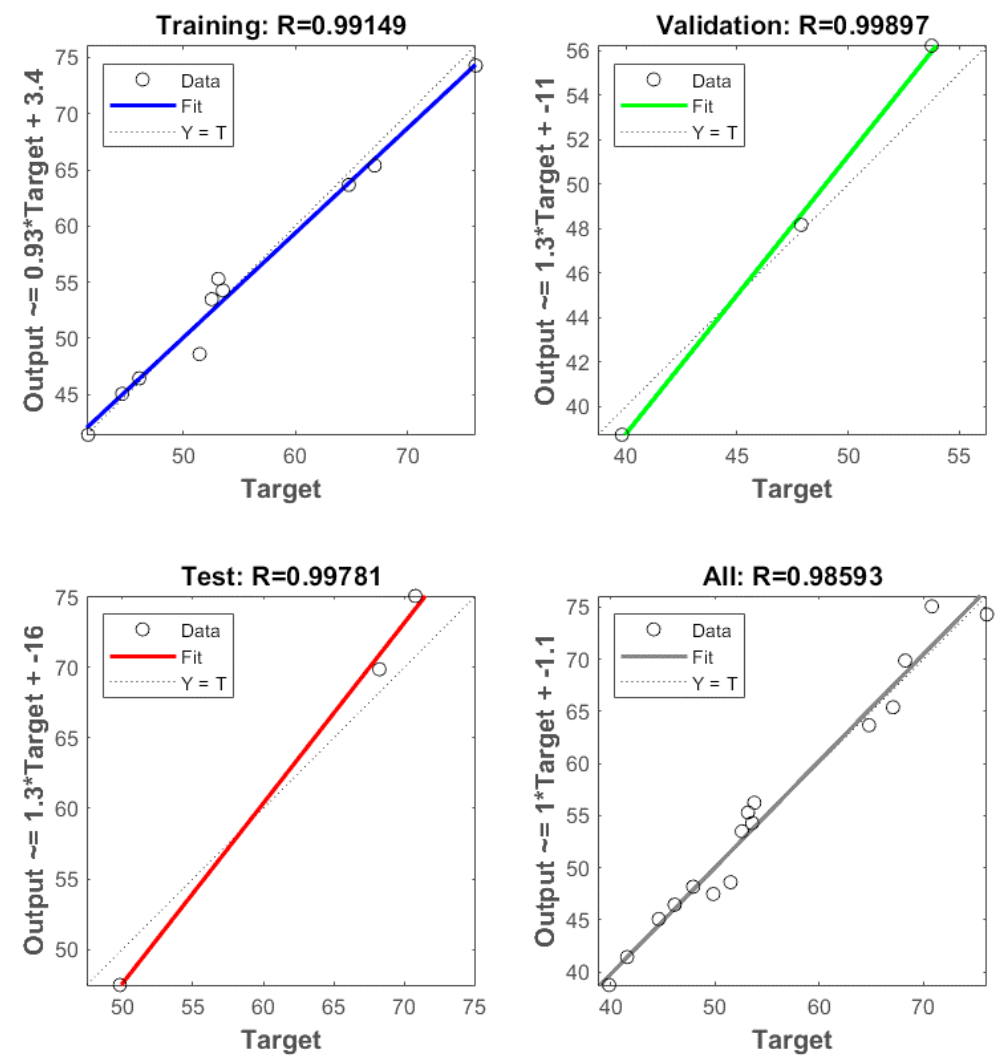

Figure 9. Coefficient of correlation (R) values of training, validation, testing and overall datasets, for elongation at break. 
Table 3. Comparison of the experimental elongation at break and predicted elongation at break by ANN model.

\begin{tabular}{|c|c|c|c|c|c|c|}
\hline $\begin{array}{l}\text { Experimental } \\
\text { Run }\end{array}$ & $\begin{array}{c}\text { Starch } \\
\text { Concentration } \\
\text { (wt.\%) }\end{array}$ & $\begin{array}{c}\text { Glycerol } \\
\text { Loading (wt.\%) }\end{array}$ & $\begin{array}{c}\text { Process } \\
\text { Temperature } \\
\left({ }^{\circ} \mathrm{C}\right)\end{array}$ & $\begin{array}{c}\text { Chitosan } \\
\text { Loading (wt.\%) }\end{array}$ & $\begin{array}{c}\text { Experimental } \\
\text { Elongation at } \\
\text { Break (\%) }\end{array}$ & $\begin{array}{c}\text { Predicted } \\
\text { Elongation at } \\
\text { Break (\%) }\end{array}$ \\
\hline 1 & 2.5 & 40 & 70 & 0 & 53.6 & 54.3 \\
\hline 2 & 5 & 40 & 70 & 0 & 51.5 & 48.6 \\
\hline 3 & 7.5 & 40 & 70 & 0 & 41.6 & 41.4 \\
\hline 4 & 5 & 50 & 70 & 0 & 53.8 & 56.2 \\
\hline 5 & 5 & 60 & 70 & 0 & 64.8 & 63.7 \\
\hline 6 & 5 & 70 & 70 & 0 & 68.2 & 69.9 \\
\hline 7 & 5 & 80 & 70 & 0 & 76.1 & 74.3 \\
\hline 8 & 5 & 40 & 65 & 0 & 39.8 & 38.7 \\
\hline 9 & 5 & 40 & 75 & 0 & 52.6 & 53.5 \\
\hline 10 & 5 & 40 & 80 & 0 & 53.2 & 55.3 \\
\hline 11 & 5 & 40 & 85 & 0 & 67.1 & 65.4 \\
\hline 12 & 5 & 40 & 90 & 0 & 70.8 & 75.1 \\
\hline 13 & 5 & 40 & 70 & 5 & 47.9 & 48.2 \\
\hline 14 & 5 & 40 & 70 & 10 & 49.8 & 47.5 \\
\hline 15 & 5 & 40 & 70 & 15 & 46.1 & 46.4 \\
\hline 16 & 5 & 40 & 70 & 20 & 44.6 & 45.1 \\
\hline$R^{2}$ & 0.9859 & & & & & \\
\hline
\end{tabular}

\subsection{FTIR}

FTIR spectra of pure starch-based bioplastic film and chitosan-reinforced starch-based bioplastic films are compared with the spectra of corn starch and chitosan powders as shown in Figure 10a. The following bands observed in the corn starch powder at $3259.86 \mathrm{~cm}^{-1}$, $2929.46 \mathrm{~cm}^{-1}$ and $1639.82 \mathrm{~cm}^{-1}$ corresponded to $\mathrm{O}-\mathrm{H}$ stretching, $-\mathrm{CH}_{2}$ stretching vibrations and $\mathrm{O}-\mathrm{H}$ bending of water, respectively, [47]. Chitosan powder showed characteristic peaks at $3293.29 \mathrm{~cm}^{-1}$, which were attributed to $\mathrm{N}-\mathrm{H}$ and $\mathrm{O}-\mathrm{H}$ stretching, $1647.44 \mathrm{~cm}^{-1}$, which was assigned to amide I ( $\mathrm{C}=\mathrm{O}$ stretching) and $1570.59 \mathrm{~cm}^{-1}$, which was assigned to amide II (C-N stretching and C-N-H bending vibrations) [48]. In the spectra of pure starch-based bioplastic film, the peaks observed at $3285.60 \mathrm{~cm}^{-1}$ and $2926.23 \mathrm{~cm}^{-1}$ were associated with $\mathrm{O}-\mathrm{H}$ and $-\mathrm{CH}_{2}$ stretching vibrations, respectively, [49]. The bands at $1648.46 \mathrm{~cm}^{-1}$ and $1411.63 \mathrm{~cm}^{-1}$ were, respectively, assigned to the $\mathrm{O}-\mathrm{H}$ bending of water and $\mathrm{CH}_{2}$ groups [50]. The typical region of saccharide bands covered $1180-953 \mathrm{~cm}^{-1}$ in which the peaks at $1150.46 \mathrm{~cm}^{-1}$ and $1077.95 \mathrm{~cm}^{-1}$ were associated to stretching vibration of $\mathrm{C}-\mathrm{O}$ in $\mathrm{C}-\mathrm{O}-\mathrm{H}$ groups, while the bands at $1015.68 \mathrm{~cm}^{-1}$ and $995.09 \mathrm{~cm}^{-1}$ were attributed to $\mathrm{C}-\mathrm{O}$ in $\mathrm{C}-\mathrm{O}-\mathrm{C}$ groups $[51,52]$.

Changes in FTIR spectrum were observed after chitosan was added to the starch-based bioplastic film. As compared with the chitosan powder, the amide I and amide II characteristic peaks of chitosan in the spectra of chitosan-reinforced starch-based bioplastic film were shifted from $1647.44 \mathrm{~cm}^{-1}$ to $1643.04 \mathrm{~cm}^{-1}$ and $1570.59 \mathrm{~cm}^{-1}$ to $1563.18 \mathrm{~cm}^{-1}$, respectively. The findings illustrated the interactions between hydroxyl groups of starch and amino groups of chitosan, which had promoted the compatibility of starch and chitosan $[44,53]$. Furthermore, the characteristic peak of inter- and intra-molecular hydrogen bonds in starch $\left(3259.86 \mathrm{~cm}^{-1}\right)$ and chitosan $\left(3293.29 \mathrm{~cm}^{-1}\right)$ were shifted to $3276.45 \mathrm{~cm}^{-1}$. This shift revealed the formation of inter- and intra-molecular hydrogen bonding between starch and chitosan [53]. Increase in the intensities of absorption peaks were noted in both pure starch-based and chitosan-reinforced starch-based bioplastic films relative to that of the corn starch and the chitosan powders as illustrated in the inset of Figure 10b. This was resulted from the overlapping of chemical bonds, indicating the presence of strong interaction between the molecules of different material components such as starch, chitosan and glycerol [54]. 

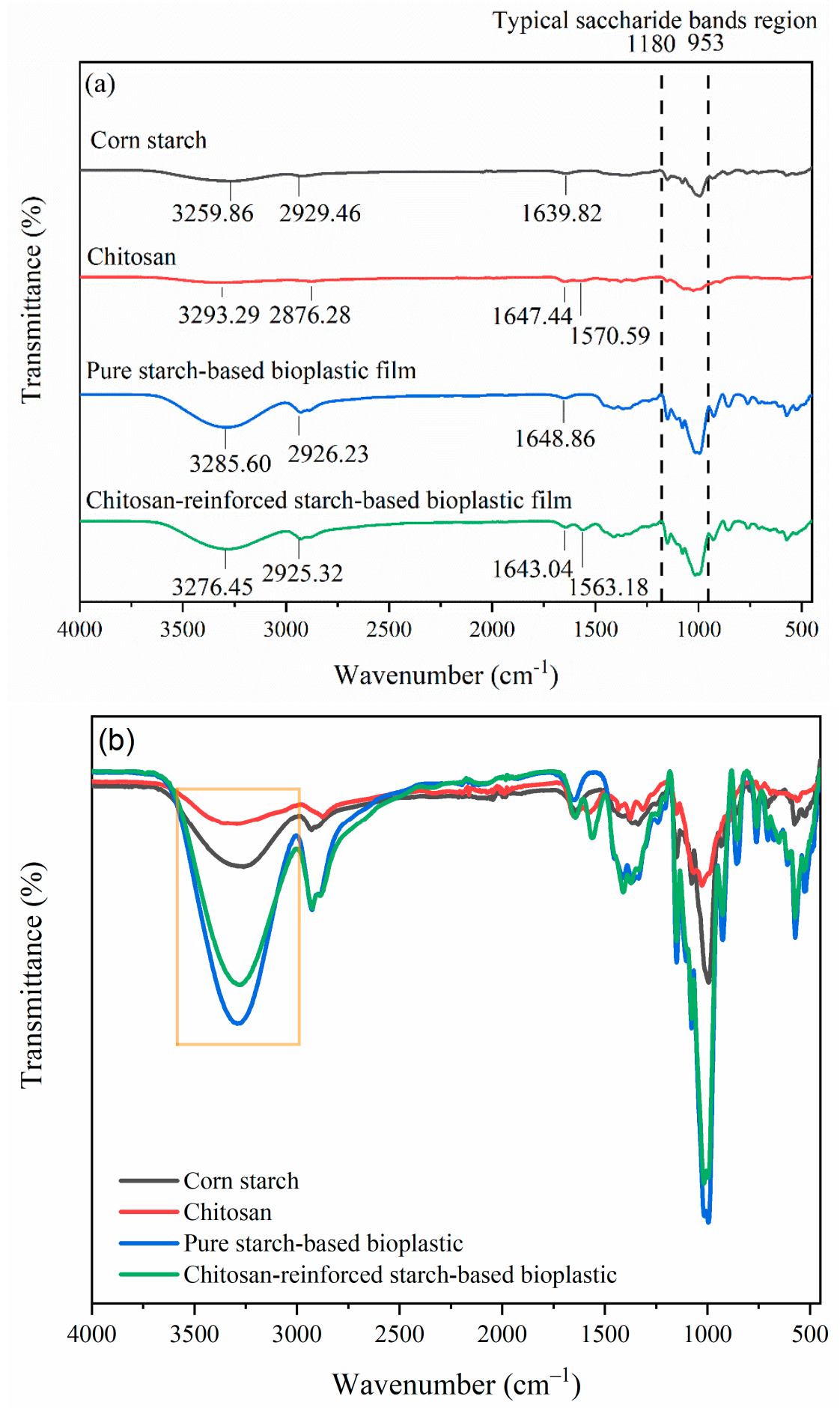

Figure 10. (a) FTIR spectra and (b) overlapping FTIR spectra of corn starch, chitosan powders, pure starch-based and chitosan-reinforced starch-based bioplastic films.

\subsection{XRD}

Figure 11 presents the $\mathrm{XRD}$ profiles of corn starch powder, pure starch-based bioplastic film, chitosan-reinforced starch-based bioplastic film and chitosan powder. The corn starch powder had diffraction peaks at $15.17^{\circ}, 17.25^{\circ}, 17.88^{\circ}, 20.25^{\circ}$ and $22.99^{\circ}$, which corresponded to A-type crystalline structure $[12,55,56]$. Unlike that of the corn starch powder, the pure starch-based bioplastic film exhibited a different XRD pattern with peaks at $17.23^{\circ}, 20.03^{\circ}, 27.49^{\circ}$ and $29.40^{\circ}$. This probably could be explained by the glycerol molecules that replaced the inter- and intramolecular hydrogen bonds, which had disrupted 
the crystallinity of starch during the bioplastic film fabrication [52]. The chitosan powder was in a crystalline state as two main diffraction peaks $\left(2 \theta=9.55^{\circ}\right.$ and $\left.20.15^{\circ}\right)$ were manifested in the XRD profile [44]. When chitosan was added into the pure starch-based bioplastic film, the crystallinity of the blend film (chitosan-reinforced starch-based bioplastic film) was decreased as reflected in the lower diffraction peaks at $20.06^{\circ}, 28.23^{\circ}$ and $30.12^{\circ}$. A similar finding was also discovered by other researchers $[50,53,57]$. The disappearance of peak at $17.23^{\circ}$ in chitosan-reinforced starch-based bioplastic film could be considered as further evidence of the interaction between starch and chitosan [53]. In addition, the characteristic peak of chitosan $\left(9.55^{\circ}\right)$ did not appear in the chitosan reinforced starch-based bioplastic film. This could be due to the formation of intermolecular hydrogen bonding between starch and chitosan, which did not favor the crystallization of starch but had altered the chitosan structure [53]. These results further corroborated the FTIR results in which there was miscibility between corn starch and chitosan owing to their intermolecular interaction.

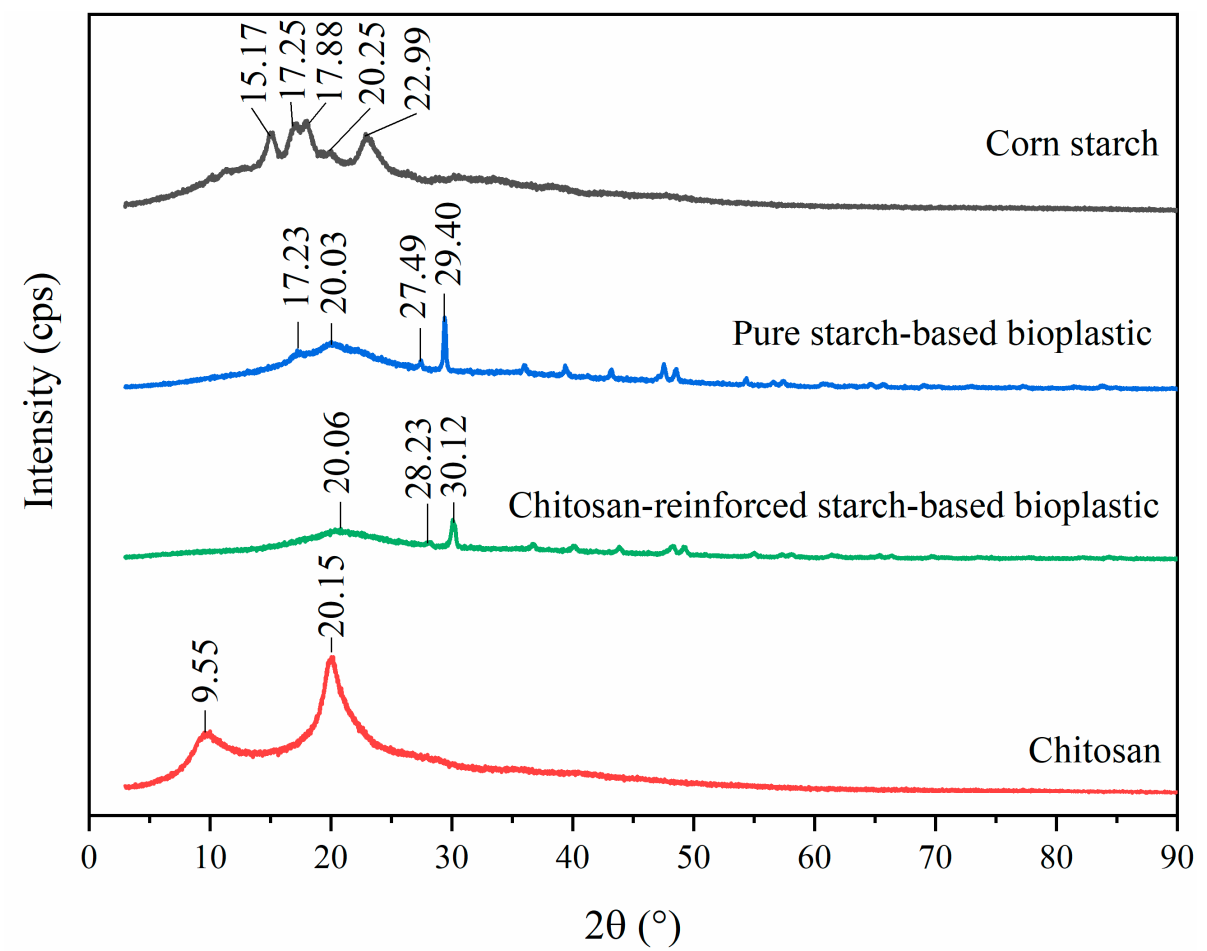

Figure 11. XRD profiles of corn starch, pure starch-based bioplastic film, chitosan-reinforced starchbased bioplastic film and chitosan.

\subsection{Thermal Analysis}

The TGA and derivative thermogravimetric (DTG) profiles of pure starch-based and chitosan-reinforced starch-based bioplastic films are shown in Figure 12a,b, respectively. There are five weight losses in both films. The first weight loss occurred between $\sim 30^{\circ} \mathrm{C}$ and $\sim 100^{\circ} \mathrm{C}$ was associated with the evaporation of free water [18]. The second weight loss took place between $\sim 100^{\circ} \mathrm{C}$ and $\sim 200^{\circ} \mathrm{C}$ was related to the evaporation of moisture from the bioplastic films [58]. The third weight loss range of $\sim 20{ }^{\circ} \mathrm{C}$ to $\sim 300{ }^{\circ} \mathrm{C}$ corresponded to the thermal decomposition of starch in bioplastic films and degradation of glycerol (boiling point of $290^{\circ} \mathrm{C}$ ) [18]. Starch contained amylose particles, which could form carbon, hydrogen and oxygen in its volatile state [59]. Around $300{ }^{\circ} \mathrm{C}$ to $\sim 500{ }^{\circ} \mathrm{C}$, compounds with lower molecular weight such as plasticizer (glycerol) and additive (chitosan) were released as well as the degradation of starch which took place at $408^{\circ} \mathrm{C}$, as shown in Figure $12 \mathrm{~b}$. Beyond $500{ }^{\circ} \mathrm{C}$, pyrolysis of carbonated compounds took place resulted in inorganic materials in the remaining residue samples [60]. 

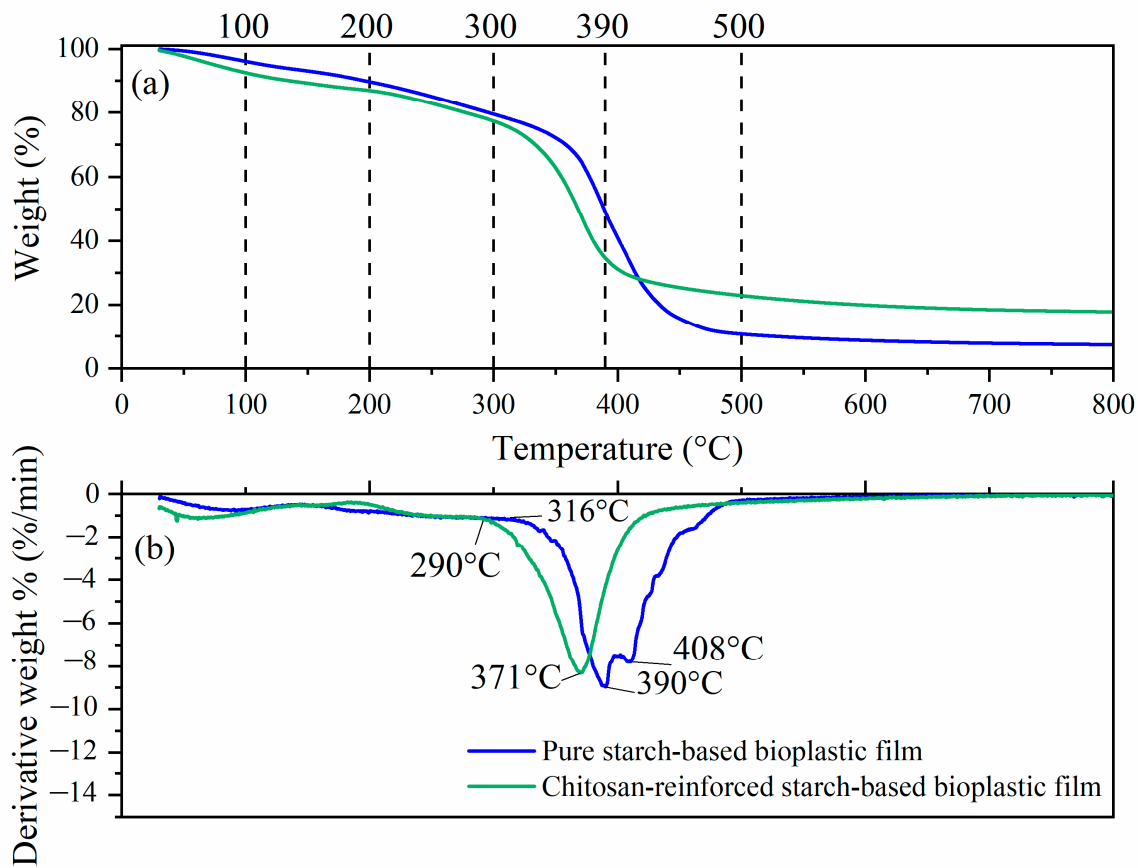

Figure 12. (a) TGA and (b) DTG curves of pure starch-based and chitosan-reinforced starch-based bioplastic films.

From the DTG curve as shown in Figure 12b, the decomposition temperatures of pure starch-based and chitosan reinforced starch-based bioplastic films were recorded at $390{ }^{\circ} \mathrm{C}$ and $371{ }^{\circ} \mathrm{C}$, respectively. The latter film had a much lower decomposition temperature, which might be attributed to the presence of acetic acid that disrupted the inter- and intra-molecular hydrogen bonds to induce thermal degradation [61,62]. Another reason could be ascribed to the decreased crystallinity in the chitosan-reinforced starch-based bioplastic film, as previously discussed in the XRD results. Film with lower crystallinity would have more molecular movement in the polymer chains and thereby lower the degradation temperature $[63,64]$. As approaching $900{ }^{\circ} \mathrm{C}$, the chitosan-reinforced starchbased bioplastic film was found to have $17 \%$ residue, which was $10 \%$ higher than pure starch-based bioplastic film with 7\% residue. From the DTG curves, as shown in Figure 12b, the results suggested that pure starch-based and chitosan-reinforced starch-based bioplastic films should be subjected to applications below $316^{\circ} \mathrm{C}$ and $290^{\circ} \mathrm{C}$, respectively, without degradation or loss of their characteristics. Most of the applications associated with this type of bioplastic, such as packaging and containers, are usually operated from room temperature to slightly higher than $100^{\circ} \mathrm{C}$. These operating temperatures are well below the thermal stability of the bioplastic films.

\subsection{Water Uptake Test}

Water uptake capability of bioplastic film is directly related to its hydrophilic nature [37]. The water uptake trends of pure starch-based and chitosan-reinforced starchbased bioplastic films of the study are depicted in Figure 13. Comparatively, chitosanreinforced starch-based bioplastic film had a lower water uptake capability. Both types of bioplastic films absorbed water rapidly within the first $10 \mathrm{~min}$ of water immersion, indicating their strong hydrophilic nature. This was due to the abundance of free hydroxyl groups available in starch and chitosan, which would allow large amount of water to penetrate into the film within minutes [10]. After $10 \mathrm{~min}$ of immersion time, starch-based bioplastic film absorbed $270 \%$ water and chitosan-reinforced starch-based bioplastic film absorbed 206\% water. Beyond $40 \mathrm{~min}$ immersion period, pure starch-based bioplastic film reached its maximum water uptake of $302 \%$, whereas the chitosan-reinforced starch-based bioplastic film only achieved a maximum water uptake of $251 \%$ after $50 \mathrm{~min}$ immersion. 
Once exceeded their respective optimum uptake threshold, both the pure starch-based and chitosan-reinforced starch-based bioplastic films showed a gradual decrease in water uptake and mass losses. The pure starch bioplastic film can be dissolved in water faster than chitosan-reinforced starch-based bioplastic film, indicating that the latter film possesses better stability in water. When the water immersion time was prolonged to $90 \mathrm{~min}$, both pure starch and chitosan-reinforced starch-based bioplastic films showed a decrease in water uptakes at $281 \%$ and $217 \%$, respectively. Comparing the maximum water uptake capability between pure starch-based bioplastic film (302\%) and chitosan-reinforced starchbased bioplastic film (251\%), the larger water uptake capability demonstrated by the latter suggesting that chitosan could be used to improve the water resistance of pure starchbased bioplastic film attributing to the hydrophilic nature of amylose. Water molecules were easily absorbed by the pure starch-based bioplastic film during immersion [4]. With the incorporation of chitosan into the starch-based bioplastic film, the interlink network formed between starch and chitosan could prevent water molecules penetrating through the film [10]. Additionally, from another perspective, water resistance of bioplastic film was enhanced by the hydrophobic nature of chitosan, which has mitigated the hydrophilic nature of starch, diminishing their interactions with water molecules $[4,65]$. The observation is in agreement with the work of Anggraini et al. [21] on sago starch-chitosan-sorbitol bioplastic film reporting a water uptake of $204.97 \%$ for bioplastic film without chitosan, and a much reduced water uptake of $130.31 \%$ in $20 \mathrm{wt} . \%$ chitosan-loaded bioplastic film.

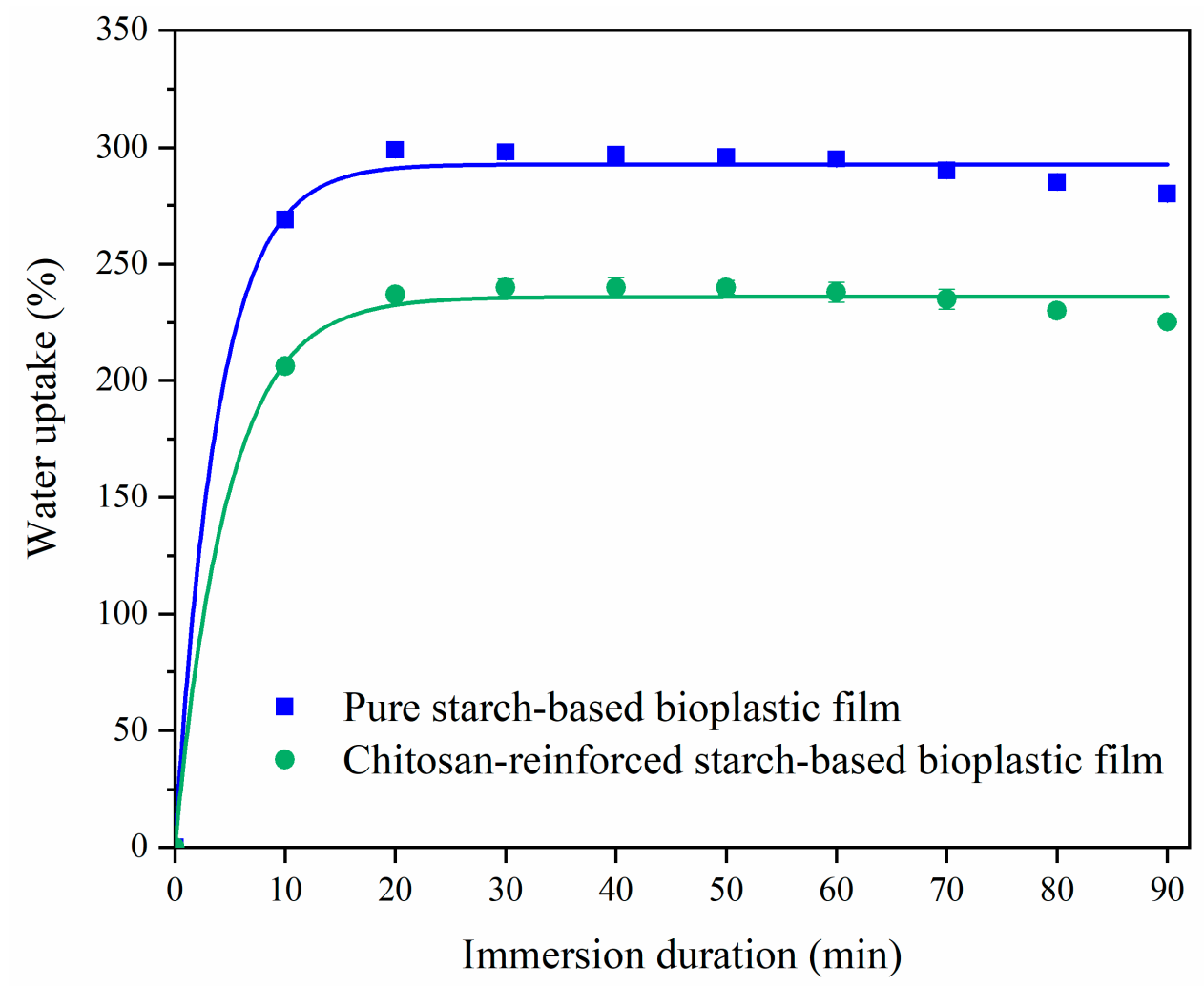

Figure 13. Water uptake percentages of pure starch-based and chitosan-reinforced starch-based bioplastic films at various immersion durations.

\subsection{Biodegradation Test}

The percentage weight losses of pure starch-based and chitosan-reinforced starchbased bioplastic films are displayed in Figure 14. The weight losses of both bioplastic films increased with the burial time, suggesting the degradation of bioplastic films. On day 7 , both films were found to have degraded by more than $40 \%$ of their initial weight. Pure starch-based bioplastic film degraded by $53.6 \%$ and chitosan-reinforced starch-based bioplastic film degraded by $47.5 \%$. There was no significant weight loss for both bioplastic 
films on the 2nd and the 3rd week. On day 28, the weight losses of pure starch-based and chitosan-reinforced starch-based bioplastic films, respectively, reached $67.7 \%$ and $52.1 \%$. Pure starch-based bioplastic film showed more weight loss than the chitosan-reinforced starch-based bioplastic film throughout the burial period, which could be due to higher hydrophilicity of the starch matrix [66]. The chitosan-reinforced starch-based bioplastic film had slower degradation, which might be due to the antimicrobial properties of chitosan as well as the interaction between starch and chitosan via hydrogen bonding, which possibly reduced the hydrophilicity of the starch matrix and thus slowing down the biodegradation rate $[34,67]$.

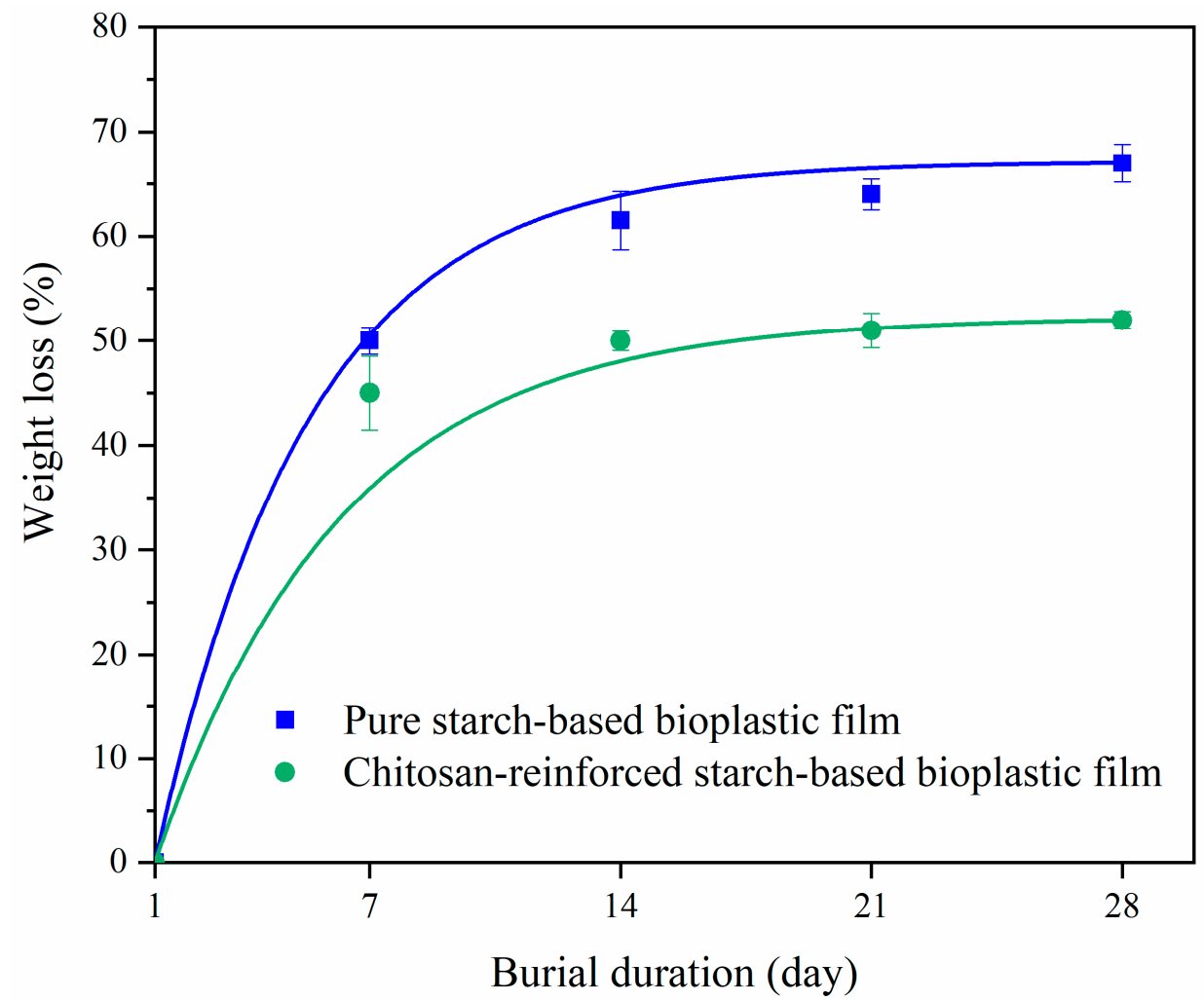

Figure 14. Weight loss percentages of pure starch and chitosan-reinforced starch-based bioplastic films during burial period.

\section{Conclusions}

Chitosan-reinforced starch-based bioplastic film was successfully prepared through the solution casting and evaporation method. This study described the effects of various parameters in attaining the optimum tensile strength of bioplastic film, and also confirmed the relationship between starch concentration and process temperature with the gelatinized duration. Higher starch concentration and process temperature would shorten the gelatinized duration and negatively affect the tensile strength. Using the hydrophobic nature of chitosan as a reinforcement agent not only could help to enhance the tensile strength, but also could improve the water resistance of starch-based bioplastic film. Although chitosan-reinforced starch-based bioplastic film could only be subjected to application below $290^{\circ} \mathrm{C}$, which was lower than pure starch-based bioplastic film $\left(316^{\circ} \mathrm{C}\right)$, it exhibited more than $50 \%$ faster biodegradability property, which will be greener for the environment.

This study has also laid the foundation in developing similar types of biodegradable chitosan-reinforced starch-based bioplastic film, which could be used to replace petroleumbased plastics. The formulation of composition based on corn starch as a matrix would also be beneficial in designing a more complete experimental study using starch derived from other agricultural waste. Although the present study demonstrated that the mechanical properties of bioplastic film were affected by the starch concentration, the relationship 
between the starch concentration and the mechanical properties of the bioplastic films is still not conclusive. Therefore, more empirical studies are required to refine and improve the reported findings.

Author Contributions: Conceptualization, S.X.T., H.C.O. and S.L.; methodology, S.X.T.; software, S.X.T. and F.K.; validation, S.X.T. and F.K.; formal analysis, S.X.T. and F.K.; investigation, S.X.T.; data curation, S.X.T. and F.K.; writing — original draft preparation, S.X.T.; writing—review and editing, A.A., G.C.N., H.C.O., S.L. and Y.L.P.; visualization, H.C.O. and Y.L.P.; supervision, A.A., G.C.N. and S.L.; project administration, S.L. and G.C.N.; funding acquisition, S.L. and G.C.N. All authors have read and agreed to the published version of the manuscript.

Funding: The research was funded under Fundamental Research Grant Scheme (FRGS/1/2018/TK10/ UTAR/02/1) from Ministry of Education, Malaysia, Universiti Malaya, Kuala Lumpur under RU Grant (GPF059A-2020) and Universiti Tunku Abdul Rahman Research Grant (UTARRF/6200-W83).

Data Availability Statement: The data presented in this study are available on request from the corresponding author.

Conflicts of Interest: The authors declare no conflict of interest.

\section{References}

1. Pathak, S.; Sneha, C.; Mathew, B.B. Bioplastics: Its timeline based scenario \& challenges. J. Polym. Biopolym. Phys. Chem. 2014, 2, 84-90. [CrossRef]

2. Zeller, M.A.; Hunt, R.; Jones, A.; Sharma, S. Bioplastics and their thermoplastic blends from Spirulina and Chlorella microalgae. J. Appl. Polym. Sci. 2013, 130, 3263-3275. [CrossRef]

3. Thiruchelvi, R.; Das, A.; Sikdar, E. Bioplastics as better alternative to petro plastic. Mater. Today Proc. 2021, 37, 1634-1639. [CrossRef]

4. Hasan, M.; Rahmayani, R. Bioplastic from Chitosan and Yellow Pumpkin Starch with Castor Oil as Plasticizer. Proc. IOP Conf. Ser. Mater. Sci. Eng. 2018, 333, 012087. [CrossRef]

5. Jiménez-Rosado, M.; Bouroudian, E.; Perez-Puyana, V.; Guerrero, A.; Romero, A. Evaluation of different strengthening methods in the mechanical and functional properties of soy protein-based bioplastics. J. Clean. Prod. 2020, 262, 121517. [CrossRef]

6. Ginting, M.H.S.; Hasibuan, R.; Lubis, M.; Tanjung, D.; Iqbal, N. Effect of Hydrochloric Acid Concentration as Chitosan Solvent on Mechanical Properties of Bioplastics from Durian Seed Starch (Durio Zibethinus) with Filler Chitosan and Plasticizer Sorbitol. Proc. IOP Conf. Ser. Mater. Sci. Eng. 2017, 180, 012126. [CrossRef]

7. Ginting, M.H.S.; Tarigan, F.R.; Singgih, A.M. Effect of gelatinization temperature and chitosan on mechanical properties of bioplastics from avocado seed starch (Persea Americana mill) with plasticizer glycerol. Int. J. Eng. Sci. 2015, 4, 36-43.

8. de Azêvedo, L.C.; Rovani, S.; Santos, J.J.; Dias, D.B.; Nascimento, S.S.; Oliveira, F.F.; Silva, L.G.; Fungaro, D.A. Study of Renewable Silica Powder Influence in the Preparation of Bioplastics from Corn and Potato Starch. J. Polym. Environ. 2021, 29, 707-720. [CrossRef]

9. Nissa, R.; Fikriyyah, A.; Abdullah, A.; Pudjiraharti, S. Preliminary study of biodegradability of starch-based bioplastics using ASTM G21-70, dip-hanging, and Soil Burial Test methods. Proc. IOP Conf. Ser. Earth Environ. Sci. 2019, 277, 012007. [CrossRef]

10. Akter, N.; Khan, R.A.; Tuhin, M.O.; Haque, M.E.; Nurnabi, M.; Parvin, F.; Islam, R. Thermomechanical, barrier, and morphological properties of chitosan-reinforced starch-based biodegradable composite films. J. Thermoplast. Compos. Mater. 2014, 27, 933-948. [CrossRef]

11. Talón, E.; Trifkovic, K.T.; Nedovic, V.A.; Bugarski, B.M.; Vargas, M.; Chiralt, A.; González-Martínez, C. Antioxidant edible films based on chitosan and starch containing polyphenols from thyme extracts. Carbohydr. Polym. 2017, 157, 1153-1161. [CrossRef] [PubMed]

12. Dome, K.; Podgorbunskikh, E.; Bychkov, A.; Lomovsky, O. Changes in the Crystallinity Degree of Starch Having Different Types of Crystal Structure after Mechanical Pretreatment. Polymers 2020, 12, 641. [CrossRef] [PubMed]

13. Souza, A.; Benze, R.; Ferrão, E.; Ditchfield, C.; Coelho, A.; Tadini, C. Cassava starch biodegradable films: Influence of glycerol and clay nanoparticles content on tensile and barrier properties and glass transition temperature. LWT-Food Sci. Technol. 2012, 46, 110-117. [CrossRef]

14. Jakubowska, E.; Gierszewska, M.; Nowaczyk, J.; Olewnik-Kruszkowska, E. Physicochemical and storage properties of chitosanbased films plasticized with deep eutectic solvent. Food Hydrocoll. 2020, 108, 106007. [CrossRef]

15. Zdanowicz, M.; Jędrzejewski, R.; Pilawka, R. Deep eutectic solvents as simultaneous plasticizing and crosslinking agents for starch. Int. J. Biol. Macromol. 2019, 129, 1040-1046. [CrossRef]

16. Chan, Y.; Phang, S.; Tee, T.; Lee, T.; Soo, T. Preliminary Study of Mechanical Properties in Thermoplastic Starch (TPS)/CoffeeWaste-Derived Fillers Composites. In Proceedings of the Engineering Undergraduate Research Catalyst Conference (EURECA), Selangor, Malaysia, 1-2 July 2015; pp. 1-14. 
17. Mallakpour, S. Fructose functionalized MWCNT as a filler for starch nanocomposites: Fabrication and characterizations. Prog. Org. Coat. 2018, 114, 244-249. [CrossRef]

18. de Azevedo, L.C.; Rovani, S.; Santos, J.J.; Dias, D.B.; Nascimento, S.S.; Oliveira, F.F.; Silva, L.G.; Fungaro, D.A. Biodegradable films derived from corn and potato starch and study of the effect of silicate extracted from sugarcane waste ash. ACS Appl. Polym. Mater. 2020, 2, 2160-2169. [CrossRef]

19. Agustin, M.B.; Ahmmad, B.; Alonzo, S.M.M.; Patriana, F.M. Bioplastic based on starch and cellulose nanocrystals from rice straw. J. Reinf. Plast. Compos. 2014, 33, 2205-2213. [CrossRef]

20. Méité, N.; Konan, L.K.; Tognonvi, M.T.; Doubi, B.I.H.G.; Gomina, M.; Oyetola, S. Properties of hydric and biodegradability of cassava starch-based bioplastics reinforced with thermally modified kaolin. Carbohydr. Polym. 2020, 254, 117322. [CrossRef]

21. Anggraini, T.; Ulfimarjan, A.F.; Yenrina, R. The effect of chitosan concentration on the characteristics of sago (metroxylon sp) starch bioplastics. Res. J. Pharm. Biol. Chem. Sci. 2017, 8, 1339-1351. [CrossRef]

22. Lopez, O.; Garcia, M.A.; Villar, M.A.; Gentili, A.; Rodriguez, M.; Albertengo, L. Thermo-compression of biodegradable thermoplastic corn starch films containing chitin and chitosan. LWT-Food Sci. Technol. 2014, 57, 106-115. [CrossRef]

23. Zakaria, N.; Muhammad, N.; Sandu, A.; Abdullah, M. Effect of Mixing Temperature on Characteristics of Thermoplastic Potato Starch Film. Drug Deliv. Syst. 2018, 5, 7. [CrossRef]

24. Yusof, Y.; Shukur, M.; Illias, H.; Kadir, M. Conductivity and electrical properties of corn starch-chitosan blend biopolymer electrolyte incorporated with ammonium iodide. Phys. Scr. 2014, 89, 035701. [CrossRef]

25. Fakhouri, F.M.; Costa, D.; Yamashita, F.; Martelli, S.M.; Jesus, R.C.; Alganer, K.; Collares-Queiroz, F.P.; Innocentini-Mei, L.H. Comparative study of processing methods for starch/gelatin films. Carbohydr. Polym. 2013, 95, 681-689. [CrossRef]

26. Kartika, T.; Harahap, M.B.; Ginting, M.H.S. Utilization of mango seed starch in manufacture of bioplastic reinforced with microparticle clay using glycerol as plasticizer. Proc. IOP Conf. Ser. Mater. Sci. Eng. 2018, 309, 012068.

27. Lubis, M.; Harahap, M.; Manullang, A.; Ginting, M.; Sartika, M. Utilization starch of jackfruit seed (Artocarpus heterophyllus) as raw material for bioplastics manufacturing using sorbitol as plasticizer and chitosan as filler. Proc. J. Phys. Conf. Ser. 2017, 801, 012014. [CrossRef]

28. Lubis, M.; Harahap, M.B.; Ginting, M.H.S.; Sartika, M.; Azmi, H. Production of bioplastic from avocado seed starch reinforced with microcrystalline cellulose from sugar palm fibers. J. Eng. Sci. Technol. 2018, 13, 381-393.

29. Maulida, S.M.; Tarigan, P. Production of starch based bioplastic from cassava peel reinforced with microcrystalline celllulose avicel PH101 using sorbitol as plasticizer. Proc. J. Phys. Conf. Ser. 2016, 710, 012012. [CrossRef]

30. Salehudin, M.H.; Salleh, E.; Mamat, S.N.H.; Muhamad, I.I. Starch based active packaging film reinforced with empty fruit bunch (EFB) cellulose nanofiber. Procedia Chem. 2014, 9, 23-33. [CrossRef]

31. Maran, J.P.; Sivakumar, V.; Thirugnanasambandham, K.; Sridhar, R. Artificial neural network and response surface methodology modeling in mass transfer parameters predictions during osmotic dehydration of Carica papaya L. Alex. Eng. J. 2013, 52, 507-516. [CrossRef]

32. Abral, H.; Basri, A.; Muhammad, F.; Fernando, Y.; Hafizulhaq, F.; Mahardika, M.; Sugiarti, E.; Sapuan, S.; Ilyas, R.; Stephane, I. A simple method for improving the properties of the sago starch films prepared by using ultrasonication treatment. Food Hydrocoll. 2019, 93, 276-283. [CrossRef]

33. $\mathrm{Wu}, \mathrm{C}$.-S. Renewable resource-based green composites of surface-treated spent coffee grounds and polylactide: Characterisation and biodegradability. Polym. Degrad. Stab. 2015, 121, 51-59. [CrossRef]

34. Sapei, L.; Padmawijaya, K.S.; Sijayanti, O.; Wardhana, P.J. The effect of banana starch concentration on the properties of chitosan-starch bioplastics. J. Chem. Pharm. Res. 2015, 7, 101-105.

35. Sultan, N.F.K.; Johari, W.L.W. The development of banana peel/corn starch bioplastic film: A preliminary study. Bioremediation Sci. Technol. Res. 2017, 5, 12-17.

36. Samer, M.; Khalefa, Z.; Abdelall, T.; Moawya, W.; Farouk, A.; Abdelaziz, S.; Soliman, N.; Salah, A.; Gomaa, M.; Mohamed, M. Bioplastics production from agricultural crop residues. Agric. Eng. Int. CIGR J. 2019, 21, 190-194.

37. Almeida, C.M.; Magalhães, J.M.; Souza, H.K.; Gonçalves, M.P. The role of choline chloride-based deep eutectic solvent and curcumin on chitosan films properties. Food Hydrocoll. 2018, 81, 456-466. [CrossRef]

38. Ginting, M.H.S.; Kristiani, M.; Amelia, Y.; Hasibuan, R. The effect of chitosan, sorbitol, and heating temperature bioplastic solution on mechanical properties of bioplastic from durian seed starch (Durio zibehinus). Int. J. Eng. Res. Appl. 2015, 6, 33-38.

39. Santana, R.F.; Bonomo, R.C.F.; Gandolfi, O.R.R.; Rodrigues, L.B.; Santos, L.S.; dos Santos Pires, A.C.; de Oliveira, C.P.; Fontan, R.d.C.I.; Veloso, C.M. Characterization of starch-based bioplastics from jackfruit seed plasticized with glycerol. J. Food Sci. Technol. 2018, 55, 278-286. [CrossRef]

40. Haryanti, P.; Setyawati, R.; Wicaksono, R. Pengaruh Suhu dan Lama Pemanasan Suspensi Pati serta Konsentrasi Butanol terhadap Karakteristik Fisikokimia Pati Tinggi Amilosa dari Tapioka. Agritech 2014, 34, 308-315. [CrossRef]

41. Zhao, Y.; Saldaña, M.D. Hydrolysis of cassava starch, chitosan and their mixtures in pressurized hot water media. J. Supercrit. Fluids 2019, 147, 293-301. [CrossRef]

42. Wojciechowska, P. The effect of concentration and type of plasticizer on the mechanical properties of cellulose acetate butyrate organic-inorganic hybrids. In Recent Advances in Plasticizers; IntechOpen: London, UK, 2012; pp. 141-164.

43. Shi, A.-M.; Wang, L.-J.; Li, D.; Adhikari, B. Characterization of starch films containing starch nanoparticles: Part 1: Physical and mechanical properties. Carbohydr. Polym. 2013, 96, 593-601. [CrossRef] 
44. Bourtoom, T.; Chinnan, M.S. Preparation and properties of rice starch-chitosan blend biodegradable film. LWT-Food Sci. Technol. 2008, 41, 1633-1641. [CrossRef]

45. Zdanowicz, M.; Johansson, C. Mechanical and barrier properties of starch-based films plasticized with two-or three component deep eutectic solvents. Carbohydr. Polym. 2016, 151, 103-112. [CrossRef]

46. Silitonga, A.; Masjuki, H.; Ong, H.C.; Yusaf, T.; Kusumo, F.; Mahlia, T. Synthesis and optimization of Hevea brasiliensis and Ricinus communis as feedstock for biodiesel production: A comparative study. Ind. Crops Prod. 2016, 85, 274-286. [CrossRef]

47. Minakawa, A.F.; Faria-Tischer, P.C.; Mali, S. Simple ultrasound method to obtain starch micro-and nanoparticles from cassava, corn and yam starches. Food Chem. 2019, 283, 11-18. [CrossRef] [PubMed]

48. Pereira, P.F.; Andrade, C.T. Optimized pH-responsive film based on a eutectic mixture-plasticized chitosan. Carbohydr. Polym. 2017, 165, 238-246. [CrossRef] [PubMed]

49. Valodkar, M.; Thakore, S. Isocyanate crosslinked reactive starch nanoparticles for thermo-responsive conducting applications. Carbohydr. Res. 2010, 345, 2354-2360. [CrossRef] [PubMed]

50. Xu, Y.; Kim, K.; Hanna, M.; Nag, D. Chitosan-starch composite film: Preparation and characterization. Ind. Crops Prod. 2005, 2, 185-192. [CrossRef]

51. Namazi, H.; Dadkhah, A. Convenient method for preparation of hydrophobically modified starch nanocrystals with using fatty acids. Carbohydr. Polym. 2010, 79, 731-737. [CrossRef]

52. Jiugao, Y.; Ning, W.; Xiaofei, M. The effects of citric acid on the properties of thermoplastic starch plasticized by glycerol. J. Starch-Stärke 2005, 57, 494-504. [CrossRef]

53. Liu, H.; Adhikari, R.; Guo, Q.; Adhikari, B. Preparation and characterization of glycerol plasticized (high-amylose) starch-chitosan films. J. Food Eng. 2013, 116, 588-597. [CrossRef]

54. Souza, V.G.L.; Pires, J.R.A.; Rodrigues, C.; Rodrigues, P.F.; Lopes, A.; Silva, R.J.; Caldeira, J.; Duarte, M.P.; Fernandes, F.B.; Coelhoso, I.M.J.C. Physical and morphological characterization of chitosan/montmorillonite films incorporated with ginger essential oil. Coatings 2019, 9, 700. [CrossRef]

55. Singh, V.; Ali, S.; Somashekar, R.; Mukherjee, P. Nature of crystallinity in native and acid modified starches. Int. J. Food Prop. 2006, 9, 845-854. [CrossRef]

56. Muñoz, L.A.; Pedreschi, F.; Leiva, A.; Aguilera, J.M. Loss of birefringence and swelling behavior in native starch granules: Microstructural and thermal properties. J. Food Eng. 2015, 152, 65-71. [CrossRef]

57. Ren, L.; Yan, X.; Zhou, J.; Tong, J.; Su, X. Influence of chitosan concentration on mechanical and barrier properties of corn starch/chitosan films. Int. J. Biol. Macromol. 2017, 105, 1636-1643. [CrossRef] [PubMed]

58. Syafri, E.; Kasim, A.; Abral, H.; Sulungbudi, G.T.; Sanjay, M.; Sari, N.H. Synthesis and characterization of cellulose nanofibers (CNF) ramie reinforced cassava starch hybrid composites. Int. J. Biol. Macromol. 2018, 120, 578-586. [CrossRef] [PubMed]

59. Wahyuningtyas, N.E.; Suryanto, H.; Rudianto, E.; Sukarni, S.; Puspitasari, P. Thermogravimetric and Kinetic Analysis of Cassava Starch Based Bioplastic. J. Mech. Eng. Sci. 2017, 1, 69-77. [CrossRef]

60. Krishnamurthy, A.; Amritkumar, P.J.S.A.S. Synthesis and characterization of eco-friendly bioplastic from low-cost plant resources. SN Appl. Sci. 2019, 1, 1432. [CrossRef]

61. Mathew, S.; Brahmakumar, M.; Abraham, T.E. Microstructural imaging and characterization of the mechanical, chemical, thermal, and swelling properties of starch-chitosan blend films. Biopolym. Orig. Res. Biomol. 2006, 82, 176-187. [CrossRef]

62. Zuraida, A.; Anuar, H.; Yusof, Y. The study of biodegradable thermoplastics sago starch. Proc. Key Eng. Mater. 2011, 471, 397-402. [CrossRef]

63. McKeen, L. Introduction to the physical, mechanical, and thermal properties of plastics and elastomers. In The Effect of Sterilization Methods on Plastics and Elastomers; Elsevier: Amsterdam, The Netherlands, 2012; pp. 57-84.

64. Klinmalai, P.; Srisa, A.; Laorenza, Y.; Katekhong, W.; Harnkarnsujarit, N. Antifungal and plasticization effects of carvacrol in biodegradable poly (lactic acid) and poly (butylene adipate terephthalate) blend films for bakery packaging. LWT 2021, 152, 112356. [CrossRef]

65. Luchese, C.L.; Pavoni, J.M.F.; dos Santos, N.Z.; Quines, L.K.; Pollo, L.D.; Spada, J.C.; Tessaro, I.C. Effect of chitosan addition on the properties of films prepared with corn and cassava starches. J. Food Sci. Technol. 2018, 55, 2963-2973. [CrossRef] [PubMed]

66. Wadaugsorn, K.; Panrong, T.; Wongphan, P.; Harnkarnsujarit, N. Plasticized hydroxypropyl cassava starch blended PBAT for improved clarity blown films: Morphology and properties. Ind. Crops Prod. 2022, 176, 114311. [CrossRef]

67. Raspo, M.A.; Gomez, C.G.; Andreatta, A.E. Optimization of antioxidant, mechanical and chemical physical properties of chitosan-sorbitol-gallic acid films by response surface methodology. Polym. Test. 2018, 70, 180-187. [CrossRef] 